Prepared for the U.S. Department of Energy under Contract DE-AC05-76RL01830

\title{
Hanford Site Guidelines for Preparation and Presentation of Geologic Information
}

\author{
DC Lanigan \\ GV Last \\ PD Thorne \\ BN Bjornstad \\ WD Webber
}

April 2010

\section{Pacific Northwest}

NATIONAL LABORATORY

Proudly Operated by Battelle Since 1965 


\title{
DISCLAIMER
}

This report was prepared as an account of work sponsored by an agency of the United States Government. Neither the United States Government nor any agency thereof, nor Battelle Memorial Institute, nor any of their employees, makes any warranty, express or implied, or assumes any legal liability or responsibility for the accuracy, completeness, or usefulness of any information, apparatus, product, or process disclosed, or represents that its use would not infringe privately owned rights. Reference herein to any specific commercial product, process, or service by trade name, trademark, manufacturer, or otherwise does not necessarily constitute or imply its endorsement, recommendation, or favoring by the United States Government or any agency thereof, or Battelle Memorial Institute. The views and opinions of authors expressed herein do not necessarily state or reflect those of the United States Government or any agency thereof.

\author{
PACIFIC NORTHWEST NATIONAL LABORATORY \\ operated by \\ BATTELLE \\ for the \\ UNITED STATES DEPARTMENT OF ENERGY \\ under Contract DE-AC05-76RL01830
}

Printed in the United States of America

Available to DOE and DOE contractors from the

Office of Scientific and Technical Information,

P.O. Box 62, Oak Ridge, TN 37831-0062;

ph: (865) 576-8401

fax: $(865)$ 576-5728

email: reports@adonis.osti.gov

\footnotetext{
Available to the public from the National Technical Information Service,

U.S. Department of Commerce, 5285 Port Royal Rd., Springfield, VA 22161

ph: (800) 553-6847

fax: $(703) 605-6900$

email: orders@ntis.fedworld.gov

online ordering: http://www.ntis.gov/ordering.htm
}

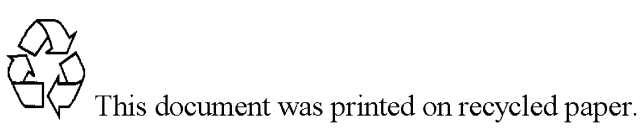

(9/2003) 


\title{
Hanford Site Guidelines for Preparation and Presentation of Geologic Information
}

\author{
DC Lanigan $\quad$ PD Thorne \\ GV Last \\ WD Webber ${ }^{1}$ \\ BN Bjornstad
}

April 2010

Prepared for

CH2M HILL Plateau Remediation Company and the U.S. Department of Energy under Contract DE-AC05-76RL01830

Pacific Northwest National Laboratory

Richland, Washington 99352

\footnotetext{
${ }^{1}$ CH2M HILL Plateau Remediation Company, Richland, Washington
} 


\section{Credits}

Acrobat, FreeHand, Illustrator, InDesign, and Photoshop are registered trademarks of Adobe Systems Incorporated. ArcInfo is a registered trademark of Environmental Systems Research Institute, Inc.

AutoCAD is a registered trademark of Autodesk, Inc.

Canvas is a trademark of ACD Systems of America, Inc.

CorelDRAW is a registered trademark of the Corel Corporation.

EarthVision is a registered trademark of Dynamic Graphics, Inc.

Hydro GeoAnalyst is a software product of Schlumberger Water Services.

Macintosh and Mac OS are registered trademarks of Apple Inc.

The Pantone Color Matching System is a trademark of Pantone, Inc., a wholly owned subsidiary of X-Rite Incorporated.

PowerPoint, Windows, and Word are registered trademarks of the Microsoft Corporation.

Rockworks and LogPlot are trademarks of Rockware, Inc.

UNIX is a registered trademark of The Open Group. 


\begin{abstract}
A complex geology lies beneath the Hanford Site in southeastern Washington State. Within this geology is a challenging large-scale environmental cleanup project. Geologic and contaminant transport information generated by several U.S. Department of Energy contractors during site characterization, remediation, and monitoring activities must be documented in geologic graphics clearly, consistently, and accurately. These graphics must then be disseminated (digitally shared) in formats readily acceptable by general graphics and document producing software applications. The guidelines presented in this document are intended to facilitate consistent, defensible, geologic graphics and digital data/graphics sharing among the various Hanford Site agencies and contractors.
\end{abstract}





\section{Acknowledgments}

The authors thank Christopher Murray for his technical review of the guidelines, and Andrea Currie for editing this document, along with providing many helpful suggestions and comments. 



\section{Acronyms and Abbreviations}

ASTM

CBRG

CYMK

DOE

DOE-RL

dpi

EPA

EPS

FGDC

GIF

HGGWG

ID

JPG

NACSN

NASC

NGMDB

OS

PDF

PNG

PS

RGB

TIFF

USGS
American Society for Testing and Materials

Columbia River Basalt Group

cyan-yellow-magenta-key black (color model)

U.S. Department of Energy

DOE Richland Operations Office

dots per inch

U.S. Environmental Protection Agency

Encapsulated PostScript

Federal Geographic Data Committee

Graphics Interchange Format

Hanford Graphics Guidelines Working Group

identification

file extension for JPEG file interchange format (JFIF)

North American Commission of Stratigraphic Nomenclature

North American Stratigraphic Code

National Geologic Map Database

operating system

Portable Document Format

Portable Network Graphic

PostScript

red-green-blue (color model)

Tagged Image File Format

U.S. Geological Survey 



\section{Terms and Definitions}

bed - the smallest formal lithostratigraphic unit of sedimentary rocks (NACSN 2005).

block diagram - an oblique view of the surface and subsurface materials and/or structures interpreted along three orthogonal axes.

borehole - a hole of circular cross-section drilled into soil or rock for subsurface sampling and/or construction of a well (ASTM D 4750, http://wapi.isu.edu/envgeo/glossary.html).

borehole log (also referred to as a geologist's log) - a form used by geologists to record observations made during drilling and sampling of borings, boreholes, and wells. May include descriptions as well as interpretations of materials encountered. This term may also be informally used as a synonym for a borehole section or borehole summary log.

borehole section - a one-dimensional representation of a boring or well that illustrates the distribution of geologic strata, including their lithology, structure, thickness, and other features.

borehole summary $\log$ - a one-dimensional representation of a boring or well that is a compilation of available hydrogeologic information obtained when drilling a borehole, including lithology, structure, and thickness, along with other borehole information, such as well construction, geophysical logs, sample analysis data, and interpretive stratigraphy.

boring - a temporary borehole intended for one-time use, that is immediately grouted and decommissioned after drilling.

columnar section - a one-dimensional representation illustrating the distribution of geologic strata, including their lithology, structure, and thickness.

driller's $\log$ - a generic term for field notes (logs) recorded by the driller (and/or drilling crew) during borehole drilling operations.

drill $\log$ - a form used by drillers in the 1970s and 1980s to record field notes.

drilling $\log -$ a form used by drillers in the 1940s through 1960s to record field notes.

facies - a mappable, areally restricted part of a lithostratigraphic body, differing in lithology from other beds deposited at the same time and in lithologic continuity.

flow - the smallest formal lithostratigraphic unit of volcanic flow rocks (NACSN 2005). A flow is a discrete, extrusive, volcanic body distinguishable by texture, composition, order of superposition, paleomagnetism, or other objective criteria. It is part of a member and thus is equivalent in rank to a bed or beds of sedimentary-rock classification. Many flows are informal units. The designation and naming of flows as formal rock-stratigraphic units should be limited to those that are distinctive and widespread.

font - any digital typeface that can normally be rendered in a variety of sizes and styles. 
formation - the fundamental formal unit in lithostratigraphic classification (NACSN 2005). A formation is a body of rock identified by lithic characteristics and stratigraphic position; it is prevailingly but not necessarily tabular and is mappable at the Earth's surface or traceable in the subsurface.

geologic cross section - a two-dimensional representation illustrating the subsurface distribution of geologic strata between points of control, such as outcrops or boreholes.

geologic fence diagram - a three-dimensional representation showing the subsurface distribution of geologic strata within panels between points of control, such as outcrops or boreholes.

geologist's log (also referred to as a borehole log) - a form used by geologists to record observations made during drilling and sampling of boreholes and wells, and/or subsampling in a laboratory. The log may include descriptions as well as interpretations of materials encountered.

geologic map - a cartographic product that portrays information about the geologic character of a specific geographic area. It is a two-dimensional representation of real-world, three-dimensional geologic features. To achieve this, a geologic map uses graphical elements to express detailed information about the different kinds of earth materials, the boundaries that separate them, and the geologic structures that have subsequently deformed them (FGDC 2006).

group - the formal lithostratigraphic unit next higher in rank to formation (NACSN 2005). A group may consist entirely of named formations, or alternatively, need not be composed entirely of named formations.

Hanford Environmental Information System (HEIS) - a consolidated set of electronic systems that store and manage data collected during environmental characterization, monitoring, and remediation at the Hanford Site.

Hanford Well Information System (HWIS) - a database that documents information about wells at the Hanford Site. Information and reports from HWIS are accessible via the HWIS web-interface, called the Well Information and Document Lookup (WIDL).

hydrostratigraphic unit - a body of rock or sediment of considerable lateral extent and having a reasonably distinct set of hydrologic properties.

isopach map - a plan view map, usually with contour lines, illustrating the variation in thickness of a geologic unit.

lithology - the physical character of a rock, generally as determined megascopically or with the aid of a low-power (e.g., 10X) magnifier.

lithostratigraphic unit - a body of rock or sedimentary strata that is defined and recognized on the basis of its lithologic properties or combination of lithologic properties and stratigraphic relations.

lithostratigraphy - the element of stratigraphy that deals with the description and nomenclature of the rocks of the Earth based on their lithology and their stratigraphic relations. 
member - the formal lithostratigraphic unit next in rank below a formation and is always part of some formation (NACSN 2005). It is recognized as a named entity within the formation because it possesses characteristics distinguishing it from adjacent parts of the formation. A formation need not be divided into members unless a useful purpose is served by doing so. Some formations may be divided completely into members; others may have only certain parts designated as members; still others may have no members. A member may extend laterally from one formation to another.

stratigraphic column - a one-dimensional representation illustrating the local/regional distribution of geologic strata, including their lithology, structure, and thickness.

stratigraphy - the element of geology that deals with the original succession and age relations of rock strata, the characteristics of rock as strata, and their interpretation in terms of depositional environment or mode of origin, and geologic history.

structure contour map - a plan view map, usually with contour lines, illustrating the elevation of a surface (either top or bottom) of a geologic unit.

text - human-readable sequence of characters (e.g., letters, numbers, symbols, and punctuation marks) and the words they may form.

time-stratigraphic unit - a stratigraphic unit that is recognized on the basis of the amounts of geologic time during which sedimentary deposition and nondeposition occurred.

typeface - a set of text characters of the same design (e.g., Arial, Century Gothic, Comic Sans MS, Helvetica, Times New Roman).

well - a permanent to semi-permanent borehole (often cased) designed for long-term repeated use. However, the term "well" is also used somewhat generically at the Hanford Site to refer to any type of borehole, particularly as it relates to their HEIS/HWIS well name or well ID.

well ID - the unique alphanumeric designation (e.g., A5481) assigned to each borehole/boring at the Hanford Site.

well name - the standard Hanford Site well name (e.g., 299-W18-1) as stored in HEIS and HWIS. Note that well names have been assigned to all types of boreholes (both borings and wells). However, not all borings have been assigned a well name consistent with the standard Hanford well name formation these cases the well name is the same as the well ID (e.g., C7515). 



\section{Contents}

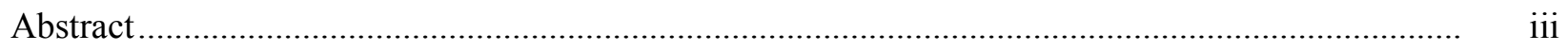

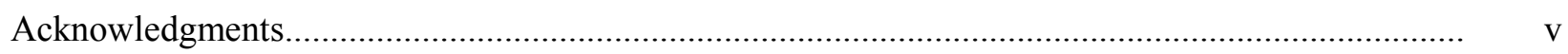

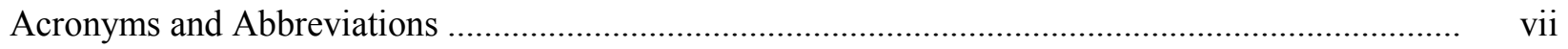

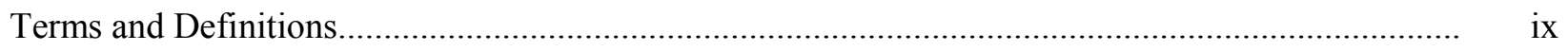

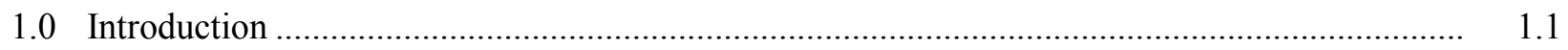

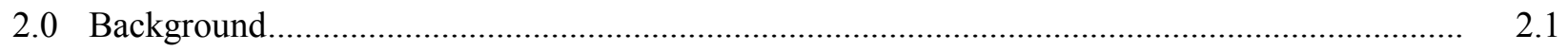

$3.0 \quad$ Purpose/Applicability ........................................................................................... 3.1

4.0 State, National, and North American Guidelines and Standards ..........................................

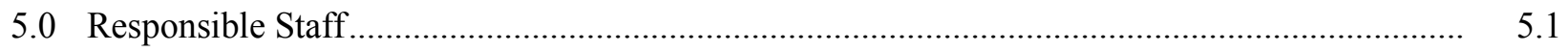

5.1 Hanford Geologic Graphics Working Group ............................................................ 5.1

5.2 Document Editors.............................................................................................. 5.1

5.3 Geologists, Hydrogeologists, and Their Designees...................................................... 5.1

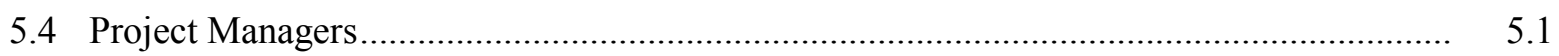

5.5 Senior Technical Reviewers ............................................................................... 5.1

6.0 General Guidance for Creating Geologic Graphics .......................................................... 6.1

6.1 Minimum Guidelines for All Geologic Graphics..................................................... 6.1

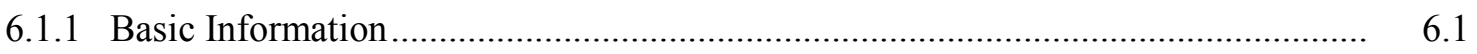

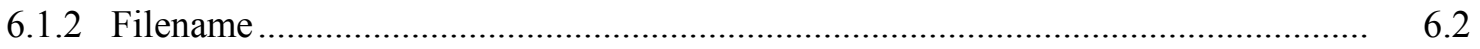

6.1.3 Lines and Labels in Graphics, Maps, and Legends ........................................... 6.2

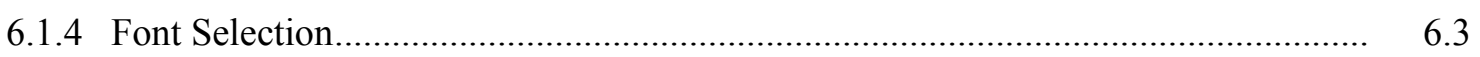

6.1.5 Recommended Font for Geologic Graphics .................................................... 6.3

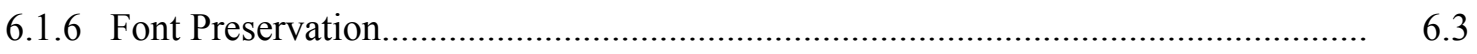

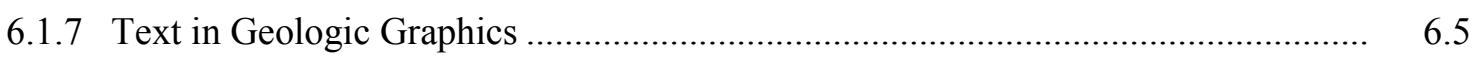

6.1.8 Electronic Graphics File Formats....................................................................... 6.5

6.1.9 Recommended Resolution for Hardcopy Reproduction...................................... 6.7

6.1.10 Recommended Resolution for Web-Based Graphics .......................................... 6.7

6.1.11 Inserting Geologic Graphics into Electronic Documents ..................................... 6.7

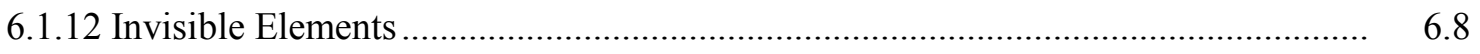

6.1.13 General Use of Color................................................................................ 6.8

6.2 Specific Guidelines for Hanford Site Lithostratigraphy............................................... 6.9

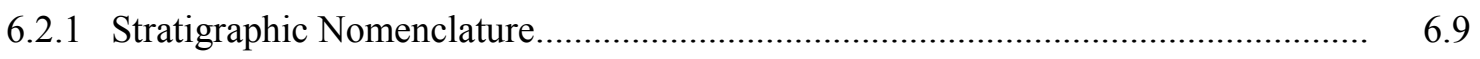

6.2.2 Color of Hanford Site Lithostratigraphic Units................................................ 6.11

6.2.3 Lithologic Patterns and Other Symbols............................................................ 6.12

7.0 Additional Guidelines for Specific Geologic Diagrams ...................................................

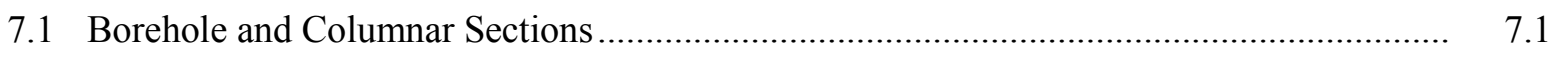

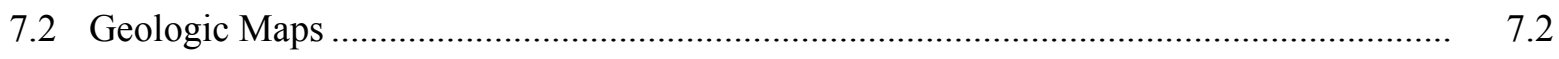




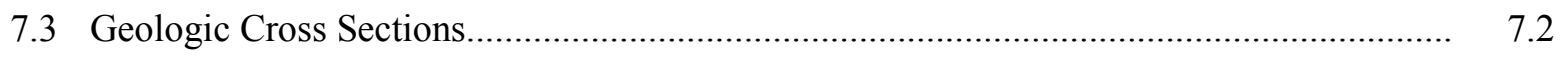

7.4 Geologic Fence/Block Diagrams........................................................................... 7.2

8.0 Examples of Software for Generating Geologic Graphics ....................................................

9.0 Geologic Graphics Database and Documentation ......................................................... 9.1

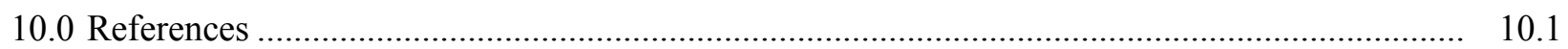

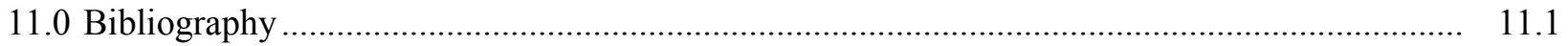

Appendix A - Lithologic and Well Completion Symbols Used at the Hanford Site......................... A.1

Appendix B - Geologic Graphics Examples .............................................................................. B. B.

\section{Figures}

6.1 Examples of text from different fonts at several relative point sizes

6.2 Examples of formal names for the Columbia River Basalt Group and informal names for sedimentary interbeds of the Ellensburg Formation beneath the Hanford Site

6.3 Examples of formal and informal nomenclature for the suprabasalt sediments beneath the Hanford Site

6.4 Generalized stratigraphic column for the Hanford Site

6.5 Hanford Site lithostratigraphic color palette with associated CMYK and RGB values

\section{Table}

6.1 Digital file formats for graphics sharing 


\subsection{Introduction}

"A picture is worth a thousand words."

Creation and presentation of accurate, consistent geologic graphics is essential to conveying the complex geology and hydrogeologic framework of the Hanford Site. A well-researched and designed graphic can be more helpful when discussing subsurface contaminant travel than even the most wellwritten paragraph or page of text. In contrast, an inaccurate or poorly designed geologic graphic can lead to confusion and hinder the understanding of important interpretations and processes.

From initial planning to final outcome of site remediation, geologic graphics are used in reports and meetings to illustrate complex geology and contaminant transport processes. In addition, geologic graphics (and other general graphics) are often the materials taken away from meetings, multimedia presentations, and workshops. These materials may then be used in other situations and media where clarity and consistency are critical to the understanding of the presented knowledge and concepts. For these reasons, it is important that Hanford Site contractors employ the set of guidelines presented in this document to create standardized geologic graphics that are accurate, consistent, reliable, and accessible to a wide audience.

CH2M HILL Plateau Remediation Company (CHPRC) requested Pacific Northwest National Laboratory (PNNL) to expand and update an unpublished document developed in $2004^{1}$ to present guidelines for standardized preparation, storage, and dissemination of geologic graphics at the Hanford Site. The guidelines in this new document are intended to be used site-wide for generating geologic graphics.

Because it helps to know why something is being asked of geologic graphics generators, the rationale for specific guidelines and recommendations also is presented in this document.

This document contains the following eleven sections and two appendices:

Section 2 is a brief overview of the Hanford Site geology, clean-up challenge, range of geologic graphics users, and reasons for this document.

Section 3 is an overview of the guidelines' purpose, examples of geologic graphics, and reasons for the guidelines.

Section 4 describes state, national, and international guidelines and standards used as a basis when developing this document for the Hanford Site.

Section 5 describes the responsibilities of staff who generate, edit, review, and approve geologic graphics.

Section 6 provides the minimum guidelines for all geologic graphics and specific guidelines for when dealing with graphics containing Hanford Site lithostratigraphy.

\footnotetext{
${ }^{1}$ Last, G. V., B. N. Bjornstad, D. C. Lanigan, W. D. Webber, and P. D. Thorne. 2004. "Hanford Site Standard for Presentation of Geologic Information.” Pacific Northwest National Laboratory, unpublished.
} 
Section 7 describes the graphic elements that should be included on borehole and columnar sections, geologic maps, geologic cross sections, and geologic fence/block diagrams.

Section 8 describes several general and specialized software applications and their vector and raster capabilities, file extensions, and compatibility issues.

Section 9 briefly describes the file requirements of a proposed geologic graphics database.

Section 10 contains all cited references.

Section 11 is a bibliography of additional information sources that may be of interest to the reader.

Appendix A provides examples of lithologic and well completion symbols in current use at the Hanford Site.

Appendix B provides examples of different types of Hanford Site-specific geologic graphics that illustrate usage of guidelines presented in this document. 


\subsection{Background}

The Hanford Site is an area of approximately 586 square miles in southeastern Washington State. The site is bounded by the Columbia River to the north and east and by the Yakima Ridge, Rattlesnake Hills, and Yakima River to the west and south. Underlying the Hanford Site is a complex geology formed by thousands of feet of many layers of flood basalts and sedimentary interbeds, hundreds of feet of sediments from many types of depositional processes, and recent surficial deposits of wind-blown sands.

Within the complex geologic setting of the Hanford Site, the U.S. Department of Energy (DOE) is engaged in one of the most complex and challenging environmental cleanup projects in history (DOE-RL 2007). A key to the success of this environmental cleanup is the ability to compile, visualize, and disseminate the vast amount of geologic information collected during site characterization, remediation, and monitoring activities.

Geologic information for the Hanford Site supports the needs of a broad range of users. These users range from planners and managers who may need generalized or schematic geologic graphics to present a cleanup concept or well location strategy, to numerical modelers who may need either a narrow or broad view of the "real world" to configure and test numerical flow and transport models, to geochemists who may need a detailed view of geologic controls on contaminant transport, to scientists and engineers designing and operating a cleanup strategy.

To increase its utility for differing uses and promote integration with related data sets produced by multiple organizations, geologic information and digital map data should be readily available, well documented, and displayed and formatted for digital sharing in a consistent manner.

In the past, many individual projects and individual contributors have of necessity developed their own practices for creating and managing geologic information and digital map data. Because the resources needed to develop widely accepted guidelines are difficult for a single organization to justify, many of these practices were developed independently, in an ad hoc fashion, with little or no input from other individuals or organizations at the Hanford Site. However, it has become increasingly clear to data producers and users that certain widely accepted guidelines and standards are essential when creating, managing, and disseminating geologic information and digital map data.

To facilitate consistency, defensibility, and digital data/graphics sharing among DOE-RL, the DOE Office of River Protection (DOE-ORP), and their subcontractors, all geologic graphics products should be produced to meet the following minimum guidelines and be made available in an electronic format to DOE subcontractors on a site-wide basis. Placing graphics onto a server in an online database accessible to all subcontractor users will lead to more consistency and less duplication of effort (i.e., cost savings) when it comes to creating and disseminating geologic graphical information. 



\subsection{Purpose/Applicability}

The purpose of these guidelines is to facilitate creation of consistent, reliable, and defensible geologic graphics for the Hanford Site and to enhance digital data/graphics sharing among Hanford Site geologists, analysts, general users, and decision makers. Included are geologic graphics generated in general graphics software (e.g., Adobe Illustrator) as well as those created using specialized graphics, numerical modeling, or geospatial analysis software (e.g., EarthVision, Hydro GeoAnalyst, Rockworks, ArcInfo, LogPlot).

These guidelines apply to work performed by geologists, hydrogeologists, and/or their designees to present and document Hanford Site geologic data and to share that data in graphical forms. Geologists use a number of techniques to create graphical representations of surface and subsurface conditions. The guidelines apply specifically to the creation, management, and dissemination of graphical representations.

Examples of common geologic graphics (graphical representations) include

- geologic features viewed from above (map view or plan view)

- geologic maps

- structure contour maps

- isopach maps

- geologic features viewed from the side (section view, elevation view, or side view)

- borehole summary logs

- columnar sections

- geologic cross sections

- stratigraphic columns

- geologic features viewed obliquely (oblique view, three-dimensional view, or isometric view

- block diagrams

- geologic fence diagrams

- three-dimensional solid model images.

All of these geologic graphics have different requirements dependent on their target audience, level of detail, and scale. A particular graphical representation created for one purpose may not be adequate for another purpose. This is often due, in part, to generalizations that are necessary for different purposes and differing scales of extent and detail (i.e., detailed localized cross section vs. generalized regional cross section).

It must be recognized that graphical representations of the surface and subsurface geologic conditions are subjective interpretations, often based on limited data, best professional judgment, and an understanding of the three-dimensional depositional and structural characteristics. Geologic interpretations are not an exact snapshot of in situ conditions because the subsurface is complex, hidden from view, and often difficult to sample. Thus, different geologists may create somewhat different 
representations of the subsurface, based on different scales, available data, and their own experience, expertise, and subjective bias. Having a standard set of symbols, colors, and best practices will better allow graphical representations, generated by and for different geologists, to be compared and used by other end users. 


\subsection{State, National, and North American Guidelines and Standards}

While the guidelines described in this document are intended for the Hanford Site, the guidelines are based on, and follow the intent of, Washington State, national, and North American geologic mapping and geologic graphics guidelines and nomenclature standards. Those guidelines and standards include

1. mechanisms now existing in the United States to promote the coordination of widely accepted, geologic mapping data-presentation standards:

- The National Geologic Mapping Act of 1992 stipulates that necessary standards be developed to support the National Geologic Map Database (NGMDB).

- The Federal Geographic Data Committee (FGDC), through its Geologic Data Subcommittee, is responsible for development of standards to support geologic data management at the federal level (i.e., FGDC Digital Cartographic Standard for Geologic Map Symbolization).

- The Association of American State Geologists has formed the Digital Geologic Mapping Committee to work with the NGMDB and the FGDC to develop mapping standards applicable to the state geological surveys.

2. U.S. Geological Survey (USGS) publications (Hansen 1991; USGS 1999, 2005, 2006) developed for authors and illustrators dealing with and generating geologic graphics

3. the revised North American Stratigraphic Code (NACSN 2005) recently published by the North American Commission on Stratigraphic Nomenclature (NACSN) - The commission is the authority on recommended procedures for classifying and naming stratigraphic and related geologic units in North America. The code is particularly helpful for the identification and usage of formal and informal lithostratigraphic nomenclature. 



\subsection{Responsible Staff}

\subsection{Hanford Geologic Graphics Working Group}

The Hanford Geologic Graphics Working Group (HGGWG) should be created that would be made up of representatives from various functions (e.g., central plateau contractor, tank farm contractor, mission support contractor, research contractor) that perform, or are responsible for producing, geologic graphics at the Hanford Site. Participants might include DOE-RL, DOE-ORP, the Pacific Northwest Site Office, and functional groups or subcontractors (e.g., CH2M HILL Plateau Remediation Company; Mission Support Alliance; Pacific Northwest National Laboratory; Washington River Protection Solutions, LLC; Bechtel National, Inc.; and Washington Closure Hanford, LLC). Members of the group should meet periodically to review geologic graphics being produced and arrive at specific recommendations to improve quality, standardization, and dissemination.

\subsection{Document Editors}

Technical editors and communications specialists from DOE and Hanford Site contractors should be aware of and promote the use of the geologic graphic guidelines when preparing/proofing reports, posters, presentations, and other documentation containing geologic graphics.

\subsection{Geologists, Hydrogeologists, and Their Designees}

Geologists, hydrogeologists, and their designees should be aware of and use the geologic graphic guidelines when preparing/proofing geologic maps, cross sections, schematic diagrams, and all other geologic graphics.

\subsection{Project Managers}

Project managers from DOE and Hanford Site contractors should be aware of and promote the use of the geologic graphic guidelines when reviewing reports, posters, presentations, and other documentation that contain geologic graphics.

\subsection{Senior Technical Reviewers}

Senior technical reviewers from DOE and Hanford Site contractors should be aware of and promote the use of the geologic graphic guidelines when reviewing reports, posters, presentations, and other documentation containing geologic graphics. 



\subsection{General Guidance for Creating Geologic Graphics}

Two main factors guide the preparation of geologic graphics:

1. purpose and use of the graphic

2. legibility of the graphic.

In preparing geologic graphics, staff should also keep in mind not only the primary use of the graphic, but possible secondary uses. For example:

- Will an 11- $\times 17$-inch formatted graphic created originally for a foldout in a report be legible if it is reduced to $8.5-\times 11$-inch format and inserted into a document in portrait or landscape orientation?

- Will a graphic that looks good in color be legible and convey the same information if printed, scanned, and/or copied in black and white or grayscale?

- Will the fonts used on the graphic remain legible after the graphic is copied, scanned, and/or resized?

\subsection{Minimum Guidelines for All Hanford Site Geologic Graphics}

The minimum guidelines for all Hanford Site geologic graphics are based on state and national guidelines along with common practices used in various geology-oriented publications. These minimum guidelines should be used for geologic graphics produced and used by Hanford Site personnel for Hanford Site publications. Graphics for use in specialized books, magazines, journals, and other documents published by offsite companies are subject to the author guidelines of those publishers (e.g., Elsevier, Geological Society of America, Wiley-Blackwell).

Geologic graphic creators should remember that a graphic must be able to "stand alone" so the end user is not required to refer to accompanying text. While a passage of text may refer to a graphic to illustrate what is being discussed, the graphic should not refer back to the text to be explained.

Unless there is an overriding programmatic or regulatory requirement, the following basic information is recommended to be on each geologic graphic.

\subsubsection{Basic Information}

graphic ID - Each graphic must have a unique alphanumeric identification assigned to it and printed on the graphic - usually in the bottom right-hand corner. This graphic ID must be retained when the graphic is inserted into any report, poster, website, or other document.

If a graphic from a published document is used in another document, the original graphic ID must be retained on the graphic. The graphic can be referenced back to its use in the previously published document by including a "from" citation in the new graphic caption - for example, (from Williams et al. 2002, p. xx, Figure X.XX).

If revisions to a graphic are made after it has been published, a new graphic ID must be assigned. The revised graphic can be referenced back to the original graphic in the previously published 
document by using an "after" citation in the graphic caption: (after Williams et al. 2002, p. xx, Figure X.XX).

Many staff use a combination of initials, date, and index number for graphic IDs (e.g., wdw04001 = first figure created by William D. Webber in 2004) or a combination of date, creator's initials, and project/task (e.g., 2009-DCL-C6210-001_03-10 = figure created in 2009 on March 10 by David C. Lanigan for borehole C6210).

legend - Each element of the graphic that is not readily identified (such as with an arrow pointing from a descriptor to the graphic element) must be identified in a legend.

scale(s) (meters and feet) - Metric and English unit scales must be used as appropriate to the scale of the graphic (i.e., centimeters and inches, meters and feet, kilometers and miles).

In the case of schematic diagrams, a label of No Scale or Not to Scale must be clearly visible on the graphic.

north arrow - Where geospatial orientation is required on a geologic graphic (such as a map, fence diagram, or block diagram), a north arrow (oriented to true north) must be clearly visible.

In the case of a cross section, the north arrow would be part of an accompanying location map.

Directional indicators (e.g., N, S, E, W, SW, NE) must be applied at both ends of the cross section if a location map is not an integral part of the cross section graphic.

location map - A location map is highly recommended for cross sections or fence/block diagrams or whenever the region shown is not obvious from the primary figure.

vertical exaggeration - If the vertical and horizontal scales of a geologic graphic are not equal, the vertical exaggeration must be indicated. Vertical exaggeration is the horizontal scale divided by the vertical scale (i.e., when horizontal scale $=250$ meters per inch and vertical scale $=25$ meters per inch, the vertical exaggeration $=10 \mathrm{X})$.

\subsubsection{Filename}

The filename of each graphic should correlate to the graphic ID. This file name should conform to current file-naming restrictions of Microsoft Windows, Apple Macintosh, and UNIX operating systems in use at the Hanford Site.

- Avoid the use of special characters including spaces, /, \, and . (except for one . (dot) preceding the file extension).

- For readability, words within filenames can be separated using - (dash) or _ (underscore).

\subsubsection{Lines and Labels in Graphics, Maps, and Legends}

- Use clean black lines, no finer than 0.5 point and no greater than 2 points, for elements of the graphic.

- Label all axes and either label or identify in a legend all graphic elements.

- Do not include general titles and descriptions in the figure; these elements are to appear in the caption, not in the graphic itself. A specific title may be used for clarity. 


\subsubsection{Font Selection}

Use a clear, sans serif font for geologic graphics. Reasons for using sans-serif fonts include the following:

- The graphic will stand out from any serif font text used in the body of a document.

- Sans-serif fonts seem to translate better to Internet web pages.

- Sans-serif fonts are more legible at small font sizes because of their even strokes.

- $\quad$ Sans-serif fonts survive reproduction and smearing because of their simple forms.

Some sans serif fonts are not recommended. Avoid using Helvetica and Arial fonts because numbers in these fonts may lose legibility (i.e., the numerals 3, 5, 6, and 9 may look like an 8) depending on font size, printer resolution, graphic scaling, and whether the graphic has been scanned, copied, rescanned, recopied, or otherwise altered electronically. See Figure 6.1 for examples of text at differing font sizes.

\subsubsection{Recommended Font for Geologic Graphics}

The recommended font for geologic graphics is the san serif font Comic Sans MS. This font is recommended due to its openness and clarity at small through large type sizes, its look in plain and bold type, its clarity on screen and on paper, and its character width and kerning. Comic Sans MS is also a system font on Microsoft Windows and Apple Macintosh operating systems.

If other sans-serif fonts are used as a second choice or for accents, make sure the fonts have common equivalents in both operating systems.

\subsubsection{Font Preservation}

Whenever possible, embed the font within the graphics file when saving or exporting the file. This is usually done by checking an option in the "Save", "Save As", or "Export" window. If the fonts used in a graphic are not included in the graphic file or in the operating system opening the file, font substitution will be required and the graphic will not look as intended (or it may be illegible).

Similar forms of many fonts are used on the various platforms (Microsoft Windows, Apple Macintosh, UNIX, and others) but may have different names on the respective platforms (e.g., Times vs. Times New Roman). However, if the corresponding characters in the substituted fonts are not exact, the appearance of the graphic will be changed to some degree when the file is opened in a different computing environment.

Converting any fonts to paths or outlines (i.e., Canvas: Object $=>$ Path $=>$ Convert to Paths) or outlines (i.e., Illustrator: Type $=>$ Create Outlines) will preserve the vector nature of the font (the "look" of the font at original and scaled sizes), but will eliminate text editing capabilities for that text. However, standard graphic editing techniques would be available when working with the converted text.

If a graphic contains converted text, separate files should then be kept of the same graphic - one file with original fonts for editing and one file with converted font vector graphics for sharing and printing across computer platforms or graphics applications. 


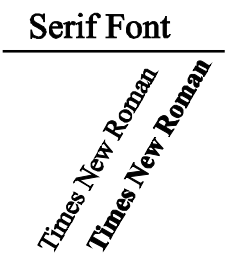

\begin{tabular}{|c|c|c|c|c|c|c|c|c|c|c|}
\hline $\begin{array}{r}\text { 18-point } \\
\text { 16-point } \\
\text { 14-point } \\
\text { 12-point } \\
\text { 10-point } \\
\begin{array}{c}\text { 8-point } \\
6-\text {-point }\end{array}\end{array}$ & $\begin{array}{l}5 \\
5 \\
5 \\
5 \\
5 \\
5 \\
5\end{array}$ & $\begin{array}{l}\mathbf{5} \\
5 \\
5 \\
5 \\
5 \\
5 \\
5 \\
5\end{array}$ & $\begin{array}{l}5 \\
5 \\
5 \\
5 \\
5 \\
5 \\
5\end{array}$ & $\begin{array}{l}5 \\
5 \\
5 \\
5 \\
5 \\
5 \\
5\end{array}$ & $\begin{array}{l}5 \\
5 \\
5 \\
5 \\
5 \\
5 \\
5\end{array}$ & $\begin{array}{l}5 \\
5 \\
5 \\
5 \\
5 \\
5 \\
5\end{array}$ & $\begin{array}{l}5 \\
5 \\
5 \\
5 \\
5 \\
5 \\
5\end{array}$ & $\begin{array}{l}5 \\
5 \\
5 \\
5 \\
5 \\
5 \\
5\end{array}$ & $\begin{array}{l}5 \\
5 \\
5 \\
5 \\
5 \\
5 \\
5\end{array}$ & $\begin{array}{l}5 \\
5 \\
5 \\
5 \\
5 \\
5 \\
5\end{array}$ \\
\hline $\begin{array}{r}\text { 18-point } \\
\text { 16-point } \\
\text { 14-point } \\
\text { 12-point } \\
\text { 10-point } \\
\text { 8-point } \\
6-\text {-point }\end{array}$ & $\begin{array}{l}6 \\
6 \\
6 \\
6 \\
6 \\
6 \\
6\end{array}$ & $\begin{array}{l}6 \\
6 \\
6 \\
6 \\
6 \\
6 \\
6\end{array}$ & $\begin{array}{l}6 \\
6 \\
6 \\
6 \\
6 \\
6 \\
6\end{array}$ & $\begin{array}{l}6 \\
6 \\
6 \\
6 \\
6 \\
6 \\
6\end{array}$ & $\begin{array}{l}6 \\
6 \\
6 \\
6 \\
6 \\
6 \\
6\end{array}$ & $\begin{array}{l}6 \\
6 \\
6 \\
6 \\
6 \\
6 \\
8\end{array}$ & $\begin{array}{l}6 \\
6 \\
6 \\
6 \\
6 \\
6 \\
6\end{array}$ & $\begin{array}{l}6 \\
6 \\
6 \\
6 \\
6 \\
6 \\
6\end{array}$ & $\begin{array}{l}6 \\
6 \\
6 \\
6 \\
6 \\
6 \\
6\end{array}$ & $\begin{array}{l}6 \\
6 \\
6 \\
6 \\
6 \\
6\end{array}$ \\
\hline $\begin{array}{r}\text { 18-point } \\
\text { 16-point } \\
\text { 14-point } \\
\text { 12-point } \\
\text { 10-point } \\
\begin{array}{c}\text { 8-point } \\
6-\text {-point }\end{array}\end{array}$ & $\begin{array}{l}8 \\
8 \\
8 \\
8 \\
8 \\
8 \\
8\end{array}$ & $\begin{array}{l}8 \\
8 \\
8 \\
8 \\
8 \\
8 \\
8\end{array}$ & $\begin{array}{l}8 \\
8 \\
8 \\
8 \\
8 \\
8 \\
8\end{array}$ & $\begin{array}{l}8 \\
8 \\
8 \\
8 \\
8 \\
8 \\
8\end{array}$ & $\begin{array}{l}8 \\
8 \\
8 \\
8 \\
8 \\
8 \\
8\end{array}$ & $\begin{array}{l}8 \\
8 \\
8 \\
8 \\
8 \\
8 \\
8\end{array}$ & $\begin{array}{l}8 \\
8 \\
8 \\
8 \\
8 \\
8 \\
8\end{array}$ & $\begin{array}{l}8 \\
8 \\
8 \\
8 \\
8 \\
8\end{array}$ & $\begin{array}{l}8 \\
8 \\
8 \\
8 \\
8 \\
8 \\
8\end{array}$ & $\begin{array}{l}8 \\
8 \\
8 \\
8 \\
8 \\
8\end{array}$ \\
\hline $\begin{array}{r}\text { 18-point } \\
\text { 16-point } \\
\text { 14-point } \\
\text { 12-point } \\
\text { 10-point } \\
\text { 8-point } \\
6 \text {-point }\end{array}$ & $\begin{array}{l}9 \\
9 \\
9 \\
9 \\
9 \\
9 \\
9\end{array}$ & $\begin{array}{l}9 \\
9 \\
9 \\
9 \\
9 \\
9 \\
9\end{array}$ & $\begin{array}{l}9 \\
9 \\
9 \\
9 \\
9 \\
9 \\
9\end{array}$ & $\begin{array}{l}9 \\
9 \\
9 \\
9 \\
9 \\
9 \\
9\end{array}$ & $\begin{array}{l}9 \\
9 \\
9 \\
9 \\
9 \\
9\end{array}$ & $\begin{array}{l}9 \\
9 \\
9 \\
9 \\
9 \\
9\end{array}$ & $\begin{array}{l}9 \\
9 \\
9 \\
9 \\
9 \\
9 \\
9\end{array}$ & $\begin{array}{l}9 \\
9 \\
9 \\
9 \\
9 \\
9\end{array}$ & $\begin{array}{l}9 \\
9 \\
9 \\
9 \\
9 \\
9 \\
9\end{array}$ & $\begin{array}{l}9 \\
9 \\
9 \\
9 \\
9 \\
9\end{array}$ \\
\hline $\begin{array}{r}\text { 18-point } \\
\text { 16-point } \\
\text { 14-point } \\
\text { 12-point } \\
\text { 10-point } \\
\text { 8-point } \\
\text { g-point }\end{array}$ & $\begin{array}{l}3 \\
3 \\
3 \\
3 \\
3 \\
3 \\
3\end{array}$ & $\begin{array}{l}3 \\
3 \\
3 \\
3 \\
3 \\
3 \\
3\end{array}$ & $\begin{array}{l}3 \\
3 \\
3 \\
3 \\
3 \\
3 \\
3\end{array}$ & $\begin{array}{l}3 \\
3 \\
3 \\
3 \\
3 \\
3 \\
3\end{array}$ & $\begin{array}{l}3 \\
3 \\
3 \\
3 \\
3 \\
3 \\
3\end{array}$ & $\begin{array}{l}3 \\
3 \\
3 \\
3 \\
3 \\
3 \\
3\end{array}$ & $\begin{array}{l}3 \\
3 \\
3 \\
3 \\
3 \\
3 \\
3\end{array}$ & $\begin{array}{l}3 \\
3 \\
3 \\
3 \\
3 \\
3 \\
3\end{array}$ & $\begin{array}{l}3 \\
3 \\
3 \\
3 \\
3 \\
3 \\
3\end{array}$ & $\begin{array}{l}3 \\
3 \\
3 \\
3 \\
3 \\
3 \\
3\end{array}$ \\
\hline
\end{tabular}

Century Gothic aA bB cC dD eE fF gG hH il jJ kK IL mM oO pP qQ rR sS tT uU vV wW $x X$ yY zZ Century Gothic aA bB CC dD eE fF gG hH il jJ kK IL $\mathrm{mM}$ oO pP qQ rR sS tr uU vV wW $x X$ yY $\mathrm{zZ}$

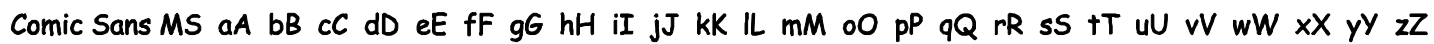

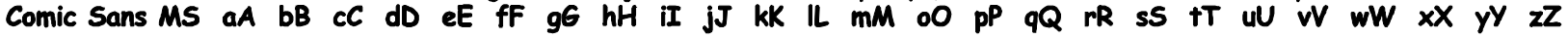

Verdana $a A$ bB $c C$ dD eE fF gG hH iI jJ kK IL $m M$ oO pP qQ rR sS tT uU vV wW $x X$ yY zZ

Verdana aA bB CC dD eE fF gG hH iI jJ kK IL mM OO pP qQ rR sS tT uU vV wW XX yY zZ

Times New Roman aA bB cC dD eE fF gG hH iI jJ kK lL mM oO pP qQ rR sS tT uU vV wW xX yY zZ

Times New Roman aA bB cC dD eE fF gG hH iI jJ kK IL mM oO pP qQ rR sS tT uU vV wW xX yY zZ

Figure 6.1. Examples of text from different fonts at several relative point sizes (figure created in Adobe Illustrator, saved as EPS file, and inserted into Word) 


\subsubsection{Text in Geologic Graphics}

Keep in mind the following when working with text in geologic graphics:

- All text should be between 6 point and 18 point type size, depending on its use in the graphic.

- Keep all text for base elements in a figure (such as axis labels, contour labels, latitude and longitude, scale text, and inset text) around the same size to aid in the reduction and/or enlargement of the figure. Text for other graphic elements can be scaled as needed for clarity and emphasis.

- Avoid unnecessary use of vibrant color or making the text too large for the figure. This can result in glaring maps and other graphics with a cartoonish appearance.

- Avoid the overuse of boldface text because the open spaces in the letters may tend to fill in when reduced. Boldface text is acceptable to emphasize elements of a graphic.

- Place a white background behind text that crosses a dark or textured area in a figure. White text may also be used, if appropriate, when labeling dark areas of a graphic.

\subsubsection{Electronic Graphics File Formats}

Depending on the content and method of creation, graphics files may be either in a vector format or a raster format or a combination of the two. Table 6.1 lists digital file formats for different image types.

Table 6.1. Digital file formats for graphics sharing

\begin{tabular}{lcc}
\hline Image Type & Vector Formats & Raster Formats \\
\hline Black and white line art & PDF, EPS, PS & PNG, GIF, JPEG, TIFF \\
\hline Grayscale line art & PDF, EPS, PS & PNG, GIF, JPEG, TIFF \\
Color line art with solid fill colors & PDF, EPS, PS & PNG, GIF, JPEG, TIFF \\
\hline Color drawings with graded colors & PDF, EPS, PS & JPEG, TIFF \\
Photographs & -- & JPEG, TIFF \\
\hline Scanned images & -- & JPEG, TIFF \\
\hline
\end{tabular}

\subsubsection{Vector Graphics}

Vector graphics may consist of lines, polygons, fills, and editable text. All these are stored within a computer program as mathematical expressions that are converted within the program to what is seen on the computer monitor and printed page. For this reason, it is possible to rescale vector graphics without losing any resolution.

Standard cross-platform vector file types include

- EPS (Encapsulated PostScript, file extension .eps) 
- PDF (Portable Document Format, file extension .pdf)

- PS (PostScript, file extension .ps).

It is best to retain vector files in vector format, rather than converting to a raster image, whenever possible. However, some software applications do not readily support the importation and use of vector formats, which makes it necessary to convert from vector to raster format. When this is done, care must be taken to retain the appropriate resolution and image quality for the intended purpose.

For vector graphics, three electronic files should be created for each figure - one in the native program, a second in a standard vector format, and the third in a standard raster format, listed in Table 6.1.

Vector file formats can also have raster images in them. If a raster image is part of the vector graphic file, remember to use a suitably high raster image resolution to complement the vector elements of the file.

\subsubsection{Raster Graphics}

Raster graphics are composed of an array of grayscale or colored dots at a specified resolution (dot density). Rescaling raster graphics to a larger size may result in a coarse image and loss of resolution compared to the original image. When a vector file is converted to a raster format, care must be taken to retain the appropriate resolution and image quality for the intended purpose.

Standard cross-platform raster file types include

- GIF (Graphics Interchange Format, file extension .gif)

- PNG (Portable Network Graphics, file extension .png)

- JPEG (Joint Photographic Experts Group, file extension .jpg)

- TIFF (Tagged Image File Format, file extension .tif)

GIF and PNG formats are generally used for line art and nongradient color fills. JPEG format is generally used for photographs and gradient color fills. TIFF files are also acceptable for some image types but may be less useful than others because of their potentially large file size.

For raster graphics, two electronic files should be created for each figure - one in the native program in which the figure was created and the other in one of the formats listed in Table 6.1.

If hardcopy figures are produced as originals by nondigital means, they should be scanned and saved in a format specified in Table 6.1 to provide an electronic record. For TIFF, JPEG, GIF, or PNG files, resolutions should be between 300 and 600 dots per inch (dpi). Generally, halftones should not be scanned at higher than $600 \mathrm{dpi}$; line art is usually good at 600 dpi. Low-resolution 72-dpi images are not acceptable.

As noted in Section 6.1.2, the graphic filename should be correlated to the graphic ID so that the graphic can be readily traced back to its source. 


\subsubsection{Recommended Resolution for Hardcopy Reproduction}

The recommended minimum resolutions for geologic graphics in general Hanford Site printed documents are as follows:

- Line art with no screening, just black, should be saved as 600 dpi at $100 \%$ size.

- Line art that has halftone screens or photos should be saved as $300 \mathrm{dpi}$ at $100 \%$ size.

- Photos alone should be saved as 300 dpi (or more).

- Color images should be saved as $300 \mathrm{dpi}$ at $100 \%$ size.

Some documents may have requirements for higher-resolution geologic graphics, and those should be used when specified.

Remember that reducing the overall size of a geologic graphic in a document will generally not affect the image quality at the recommended resolutions. However, if there is a chance the graphic would be enlarged, a suitably higher resolution will be required.

\subsubsection{Recommended Resolution for Web-Based Graphics}

All graphics for display by a web browser should be saved as $72 \mathrm{dpi}$, with a link to a high-resolution file for printing purposes.

\subsubsection{Inserting Geologic Graphics into Electronic Documents}

Geologic graphics may be generated by several methods. For example,

- scanning a hardcopy graphic, making it a raster image

- tracing the raster image with a vector tool, making it a vector image

- building a graphic from scratch using vector and/or raster tools.

These graphics could then be exported as a file type that can be imported into another graphics application or inserted into a text processing application.

It may take years (if ever) for applications code writers to perfect graphics conversion algorithms, especially for converting between different vector formats or between vector and raster formats. An application (graphics or text) that imports or exports a specific format does not necessarily do so correctly or accurately $100 \%$ of the time. Even the same application on different computing platforms (e.g., Macintosh, Windows) may handle graphics importing and exporting differently.

If exact replication of a graphic is required, it is best to test the import/export filters of both the generating graphics application and the application into which the graphic is going to be inserted.

Although acceptable for drafts, cutting and pasting graphics between different applications should be avoided for final preparation of a graphic before final printing or converting into PDF format. 
Because of the way different graphics formats are handled internally by different word processing programs, it is best to insert geologic (and all other) graphics from the original graphics file into the word processing file. For example, to insert a graphics file into a Word document,

- on a Macintosh operating system (OS) computer: Insert $=>$ Picture $=>$ From File...

- on a Windows OS computer: Insert $=>$ Picture.

This is especially important when a researcher may be using a Mac OS computer and the text or document processor is using a Windows OS computer, or the researcher is using a Windows OS computer and the text or document processor is using a Mac OS computer. Although both the researcher and document processor may be using Word, graphics in Word on the two OS platforms are not necessarily shared or handled the same way, once the graphics are in Word. Other applications and operating systems will have their own peculiarities. Different versions of the same application may compound the problem.

Remember to either embed fonts or create font outlines in vector graphics files when they are to be inserted into other applications. This is especially important when the original graphic is generated by a specialized application that has a particular font set included when the application is installed (e.g., ArcInfo uses ESRI fonts for symbols and shapes, and those fonts must be converted to outlines or embedded if the generated graphic is to be used in other programs and operating systems not having access to ESRI fonts). The text or document processors placing the graphic in a report may not have the ESRI fonts on their computers.

Remember to always print the document before final duplication, as what is seen on the computer monitor may not be what is output on a printer or plotter.

\subsubsection{Invisible Elements}

Many graphics files contain unnecessary invisible elements. These are sometimes imported graphics over which the creator of the file has traced and then set to not print. It is best to delete the unnecessary element(s) or layer(s) rather than just set it to not print. Invisible elements may contain sensitive information that must be reviewed or removed prior to transmitting the file.

\subsubsection{General Use of Color}

When using color in geologic graphics, the goal is to enhance the legibility of the graphic as well as to lend meaning to the data presented by focusing attention on or identifying a specific geologic feature or a number of features.

- For hardcopy dissemination only, color graphics should be saved in the cyan-magenta-yellow-key black (CYMK) color mode.

- For display by a web browser only, color graphics should be saved in the red-green-blue (RGB) color mode.

Note that colors will vary from monitor to monitor and from printer to printer unless Pantone-certified monitors, software, and printers are used and configured for Pantone reproduction. Even two printers of 
the same make and model may print colors differently, depending on toner or ink levels and type of paper used.

Keep in mind that colors on a computer monitor will look different on paper when printed on generalpurpose laser or ink jet printers.

Typical liquid crystal display (LCD) or cathode ray tube (CRT) monitors use transmitted RGB light and can vary in their number of colors displayed and their resolution. As more color is added on a monitor, more light is added and transmitted to the viewer as well. This is different from what one sees on the printed page.

What one sees on hardcopy output from typical color laser printers and high-end color plotters is produced by ambient light being reflected and absorbed by CMYK toner or ink colors on the printed paper. Adding greater percentages of CMYK toner or ink in a combination color will result in more light being absorbed and less light being reflected to the viewer, which may make the color appear dull on the paper.

\subsection{Specific Guidelines for Hanford Site Lithostratigraphy}

\subsubsection{Lithostratigraphic Nomenclature}

Hanford Site stratigraphic nomenclature changes and evolves as more is learned about the lithologies and depositional environments of the suprabasalt sediments and Columbia River Basalt Group beneath the site. Formal lithostratigraphic names, informal lithostratigraphic names, and very informal, localized lithostratigraphic names have been and continue to be used in geologic graphics.

Correct and consistent use of formal and current informal lithostratigraphic nomenclature is critical for clear communication between the numerous governmental entities (local, state, and federal), contractors, and subcontractors involved with geologic information gathered at the Hanford Site.

Both formal and informal nomenclature have been used over the years to name sedimentary units and flood basalt units beneath the Hanford Site. It is apparent from surveying Hanford Site communications products (e.g., reports, posters, presentations) that correct lithostratigraphic nomenclature has neither been, nor is being, used with an acceptable level of consistency. However, it is essential to use the formal unit names and most current informal unit names to help geologic data generators and users effectively communicate and understand each other.

It is important to use proper capitalization of lithostratigraphic names in text, figures, and tables to denote the formal or informal nature of those names. The U.S. Geological Survey (Hansen 1991) provides this summary of formal versus informal usage:

The distinction between formal and informal stratigraphic nomenclature must be kept clear throughout reports and maps. Follow guidelines in the North American Stratigraphic Code (1983) [updated in 2005] for formal nomenclature. Describe informal nomenclature and the style of its use early in a report. For informal nomenclature, do not use a geographic name as a subject nominative until the informal status is made clear in a report. Stratigraphic rank terms - such as supergroup, group, formation, member, bed, 
supersuite, suite, and complex - should never be used after a place or geographic name in informal nomenclature. In reports describing informal stratigraphic units, rock names must be connected indirectly with geographic names in the abstract, introduction, stratigraphic description, and conclusion of the text and in tables, illustrations, and plates.

The North American Stratigraphic Code (NACSN 2005) describes formal and informal units as follows:

Formally named units are those that are named in accordance with an established scheme of classification; the fact of formality is conveyed by capitalization of the initial letter of the rank or unit term (for example, Ringold Formation). Formalization is appropriate for those units requiring stability of nomenclature, particularly those likely to extend far beyond the locality in which they were first recognized.

Informal units, whose unit terms are ordinary nouns, are not protected by the stability provided by proper formalization and recommended classification procedures. Informal terms are appropriate for casually mentioned and innovative units, and those that may be too thin to map at usual scales.

The formal name of a lithostratigraphic unit is compound. It consists of a geographic name combined with a descriptive lithic term or with the appropriate rank term, or both. Initial letters of all words used in forming the names of formal rock-stratigraphic units are capitalized (NACSN 2005).

Examples of formal, informal, and historical informal (i.e., names that do not adhere to the above convention) lithostratigraphic names being used at the Hanford Site include

- formal - Columbia River Basalt Group, Ellensburg Formation, Saddle Mountains Basalt (among other formally named basalts), and Ringold Formation

- informal - member of Wooded Island, member of Taylor Flat, member of Savage Island, unit A (and $\mathrm{B}, \mathrm{C}, \mathrm{D}, \mathrm{E})$, and lower mud unit

- historical informal -Hanford formation.

For clarity, informal naming must be adhered to in document text, section headings, captions, labeling, and elements of graphics (i.e., Cold Creek unit - not Cold Creek Unit; Hanford formation - not Hanford Formation; member of Savage Island - not Savage Island Member; Ringold Formation lower mud unit - not Ringold Lower Mud).

For the basalt flows beneath the Hanford Site, the flood basalts of the Columbia River Basalt Group (CRBG) have been formally named (Swanson et al. 1979). The intercalated sedimentary Ellensburg Formation has also been formally named (Delany et al. 1991). The individual sedimentary interbeds of the Ellensburg Formation, found between basalt flows, have been only informally named. Figure 6.2 is the formal stratigraphic nomenclature of the CBRG and the informal interbed nomenclature of the Ellensburg Formation below the site down through the Saddle Mountains Basalt. Because most boreholes drilled at the Hanford Site that go to and into basalt encounter only the Saddle Mountains Basalt, the other basalt formations of the CRBG are not shown in Figure 6.2 for simplicity. See Swanson et al. (1979) or Delany et al. (1991) for the names of deeper basalt formations. 


\begin{tabular}{|c|c|c|}
\hline Group & Formation & Member - interbed \\
\hline 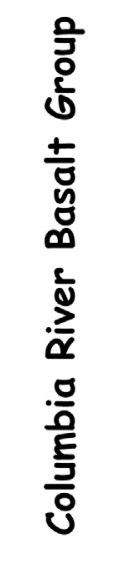 & 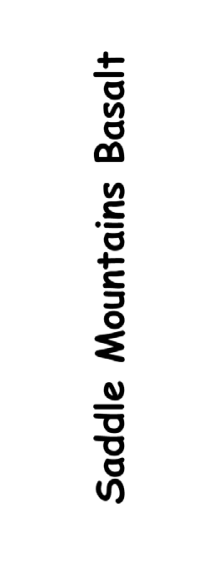 & $\begin{array}{l}\text { Ice Harbor Member } \\
\text { - Levey interbed } \\
\text { Elephant Mountain Member } \\
\text { - Rattlesnake Ridge interbed } \\
\text { Pomona Member } \\
\text { - Selah interbed } \\
\text { Esquatzel Member } \\
\text { - Cold Creek interbed } \\
\text { Asotin Member } \\
\text { Wilbur Creek Member } \\
\text { Umatilla Member }\end{array}$ \\
\hline
\end{tabular}

Figure 6.2. Examples of formal names for the Columbia River Basalt Group and informal names for sedimentary interbeds of the Ellensburg Formation beneath the Hanford Site (600-dpi grayscale TIFF file inserted into Word)

For the suprabasalt sediments, in which most contaminants are found and most fate and transport studies are done, only the Ringold Formation has been named formally (Lindsey 1995, 1996). Units within the Ringold Formation and those units above them have been named only informally, with the informal nomenclature changing over time and by researcher. Figure 6.3 has examples of nomenclature in current use for Hanford Site suprabasalt sediments.

Graphics representing hydrogeologic units defined for flow and transport models may have those units defined as one or more hydro- or lithostratigraphic units, and model-specific identifiers may be used. See Williams et al. (2001, 2002) and Wurstner et al. (1995).

Avoid mixing hydro- and lithostratigraphic nomenclature in the same name (i.e., Ringold Formation Unit 5, Hanford Unit 1, Cold Creek Unit 2).

Figure 6.4 is an example of proper usage and capitalization of the generalized Hanford Site stratigraphy (both hydrostratigraphy and lithostratigraphy).

\subsubsection{Color of Hanford Site Lithostratigraphic Units}

When using color specifically for the suprabasalt lithostratigraphy underlying the Hanford Site, the recommended color palette is that shown in Figure 6.5. This localized color palette was developed for lithology-based graphics rather than using time-stratigraphic-based colors.

Because of the many lithostratigraphic units of Pliocene, Pleistocene, and Holocene age under the Hanford Site, it is not feasible to use the age-based American color system developed by the USGS for geologic maps (USGS 2005). However, the USGS intent for color use has been followed here, along with honoring, as much as possible, colors used previously at the Hanford Site. 


\begin{tabular}{|c|l|}
\hline Formal Name & informal nomenclature (symbol) \\
\hline \multirow{7}{*}{$\begin{array}{l}\text { backfill } \\
\text { Holocene deposits - sand (HDs) }\end{array}$} & $\begin{array}{l}\text { Hanford formation } \\
\text { Hanford formation unit 1 (H1) } \\
\text { Hanford formation unit 2 (H2) } \\
\text { Hanford formation unit 3 (H3) }\end{array}$ \\
\hline & $\begin{array}{l}\text { Cold Creek unit } \\
\text { Cold Creek unit - silt dominated (CCUz) } \\
\text { Cold Creek unit - calcic (CCUC) } \\
\text { Cold Creek unit - gravel dominated (CCUg) }\end{array}$ \\
\hline Ringold Formation & $\begin{array}{l}\text { member of Savage Island } \\
\text { member of Taylor Flat (Rtf) } \\
\text { member of Wooded Island (Rwi) } \\
\text { member of Wooded Island - unit E (Rwie) } \\
\text { member of Wooded Island - unit C (Rwic) } \\
\text { member of Wooded Island - unit B (Rwib) } \\
\text { member of Wooded Island - unit D (Rwid) } \\
\text { member of Wooded Island - lower mud unit (RIm) } \\
\text { member of Wooded Island - unit A (Rwia) }\end{array}$ \\
\hline \multicolumn{1}{|c|}{ 2010-DCL-GeoGraphStan-005_04-09 }
\end{tabular}

Figure 6.3. Examples of formal and informal nomenclature for the suprabasalt sediments beneath the Hanford Site (600-dpi grayscale TIFF file inserted into Word)

The Hanford Site suprabasalt lithostratigraphic color palette includes

- light yellow for Holocene deposits

- yellows for Hanford formation

- beiges for Cold Creek unit

- greens for Ringold Formation

- intra-unit colors that are more pronounced at greater stratigraphic depths.

Grays are used for the underlying basalt.

\subsubsection{Lithologic Patterns and Other Symbols}

Recommended lithologic patterns and well completion symbols are presented in Appendix A. These are based on the patterns and symbols in use at the Hanford Site since 1987 (Last and Liikala 1987) and referenced in geologic logging procedures of the primary Hanford Site contractors (e.g., PNNL-MA-567, DO-1; Groundwater Protection Program Procedure CP-GPP-EE-01-7.0). Other symbols or colors, though not recommended, may be used for clarity as long as they are defined in a legend. 


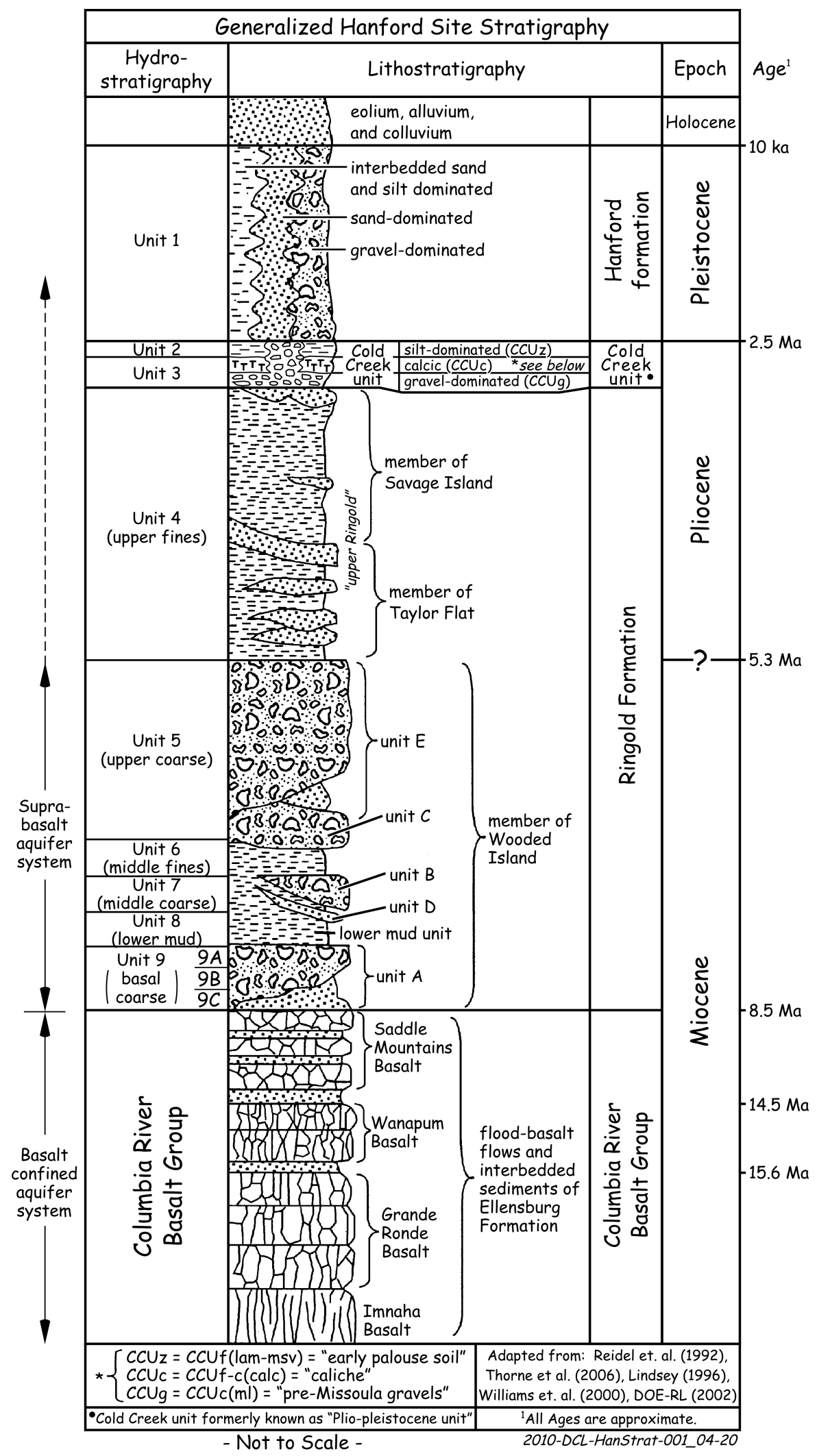

Figure 6.4. Generalized stratigraphic column for the Hanford Site (figure created in Canvas, saved as 600-dpi PNG file, inserted into Word, and reduced in size) 
Geologic contacts on cross sections or fence diagrams should be represented as follows:

- formation vs. facies - Distinguish geologic formations from facies using a heavier line weight for formation contacts.

- observed - Use a solid line to connect known points of contact.

- inferred - Use a dashed line to connect inferred or questionable points of contact, and query (?) where unknown. 


\begin{tabular}{|c|c|c|c|c|c|c|c|}
\hline $\begin{array}{c}\text { Siratigraphic Unit } \\
\text { (Symbol) }\end{array}$ & \begin{tabular}{|l|}
$\mathrm{C} \%$ \\
$\mathrm{M} \%$ \\
$\mathrm{Y} \%$ \\
$\mathrm{~K} \%$ \\
\end{tabular} & \begin{tabular}{|l|}
$R$ \\
$G$ \\
$B$ \\
\end{tabular} & Color & Color & \begin{tabular}{|l|}
$R$ \\
$G$ \\
$B$ \\
\end{tabular} & $\begin{array}{l}C \% \\
Y \% \% \\
Y \% \\
\%\end{array}$ & $\begin{array}{l}\text { Strutigrophic Unit } \\
\text { (Symbol) }\end{array}$ \\
\hline Backfill (Bf) & \begin{tabular}{|c|}
2 \\
0 \\
10 \\
2 \\
\end{tabular} & $\begin{array}{l}239 \\
241 \\
220\end{array}$ & Bf & $B f$ & \begin{tabular}{|l|}
239 \\
241 \\
220
\end{tabular} & \begin{tabular}{|c|}
2 \\
0 \\
10 \\
2 \\
\end{tabular} & Backill (Bf) \\
\hline $\begin{array}{l}\text { Holocene deposits, sand } \\
\text { (HDs) }\end{array}$ & \begin{tabular}{|c|}
0 \\
0 \\
20 \\
2
\end{tabular} & $\begin{array}{l}248 \\
244 \\
199\end{array}$ & HDs & HDs & $\begin{array}{l}248 \\
244 \\
199\end{array}$ & \begin{tabular}{|c|}
0 \\
0 \\
20 \\
2 \\
\end{tabular} & $\begin{array}{l}\text { Holocene deposits, sand } \\
\text { (HDs) }\end{array}$ \\
\hline $\begin{array}{l}\text { Henford formation unit } 1 \\
\text { (HI) }\end{array}$ & \begin{tabular}{|c|}
0 \\
0 \\
35 \\
4 \\
\end{tabular} & $\begin{array}{l}244 \\
236 \\
163\end{array}$ & H1 & \multirow{3}{*}{ H-undiff. } & \multirow{3}{*}{$\begin{array}{l}255 \\
231 \\
95\end{array}$} & \multirow{3}{*}{$\begin{array}{c}0 \\
5 \\
70 \\
0\end{array}$} & \multirow{3}{*}{$\begin{array}{l}\text { Hanford formation } \\
\text {-undifferentiated }\end{array}$} \\
\hline $\begin{array}{l}\text { Honford formation unit } 2 \\
\text { (H2) }\end{array}$ & $\begin{array}{c}0 \\
0 \\
50 \\
2\end{array}$ & $\begin{array}{l}245 \\
234 \\
133\end{array}$ & H2 & & & & \\
\hline $\begin{array}{l}\text { Honford formation unit } 3 \\
\text { (H3) }\end{array}$ & \begin{tabular}{|c|}
0 \\
0 \\
70 \\
2
\end{tabular} & $\begin{array}{l}252 \\
238 \\
94 \\
\end{array}$ & H3 & & & & \\
\hline $\begin{array}{l}\text { Cold Croek unit-silt } \\
\text { dominated (C(Uz) }\end{array}$ & \begin{tabular}{c|}
0 \\
15 \\
30 \\
0
\end{tabular} & $\begin{array}{l}253 \\
223 \\
172\end{array}$ & $\mathrm{CCU}_{\mathrm{z}}$ & \multirow{3}{*}{ CCU-undiff. } & \multirow{3}{*}{$\begin{array}{l}250 \\
198 \\
125\end{array}$} & \multirow{3}{*}{$\begin{array}{c}0 \\
20 \\
50 \\
0\end{array} \mid$} & \multirow{3}{*}{$\begin{array}{l}\text { Cold Crosk unit } \\
\text {-undifferentioted }\end{array}$} \\
\hline $\begin{array}{l}\text { Cold Creek unit - colcic } \\
\text { (CCUc) }\end{array}$ & \begin{tabular}{|c|}
0 \\
20 \\
30 \\
0
\end{tabular} & $\begin{array}{l}249 \\
199 \\
162 \\
\end{array}$ & CCUc & & & & \\
\hline $\begin{array}{l}\text { Cold Creok unit - gravel } \\
\text { dominated (CCUg) }\end{array}$ & \begin{tabular}{|c|}
0 \\
25 \\
45 \\
6 \\
\end{tabular} & $\begin{array}{l}228 \\
173 \\
122\end{array}$ & $\mathrm{CCUg}$ & & & & \\
\hline $\begin{array}{l}\text { Ringold Formation } \\
\text { member of Toylor Flat } \\
\text { (Rff) }\end{array}$ & \begin{tabular}{|c|}
10 \\
0 \\
40 \\
0
\end{tabular} & $\begin{array}{l}226 \\
236 \\
160\end{array}$ & Rtf & \multirow{4}{*}{ R-undiff. } & \multirow{4}{*}{$\begin{array}{l}200 \\
223 \\
120\end{array} \mid$} & \multirow{4}{*}{$\left|\begin{array}{c}20 \\
0 \\
60 \\
0\end{array}\right|$} & \multirow{4}{*}{$\begin{array}{l}\text { Ringold Formation } \\
\text {-undifferentiated }\end{array}$} \\
\hline $\begin{array}{l}\text { Ringold Formation } \\
\text { member of Wooded } \\
\text { Island - unit E (Rwie) }\end{array}$ & $\begin{array}{c}20 \\
0 \\
50 \\
0\end{array}$ & $\begin{array}{l}199 \\
224 \\
139\end{array}$ & $R w i_{e}$ & & & & \\
\hline $\begin{array}{l}\text { Ringold Formation - } \\
\text { lower mud (Rlm) }\end{array}$ & $\begin{array}{c}30 \\
0 \\
40 \\
0 \\
\end{array}$ & $\begin{array}{l}170 \\
214 \\
159\end{array}$ & $\mathrm{R} / \mathrm{m}$ & & & & \\
\hline $\begin{array}{l}\text { Ringold Formotion } \\
\text { member of Wooded } \\
\text { Island - unit A (Rwi })\end{array}$ & \begin{tabular}{c|}
40 \\
0 \\
70 \\
0
\end{tabular} & $\begin{array}{l}147 \\
201 \\
103\end{array}$ & $R w i_{0}$ & & & & \\
\hline $\begin{array}{l}\text { Saddle Mountains Basalt } \\
\text { Formation, Elephant } \\
\text { Mountain Member (Tem) }\end{array}$ & $\begin{array}{c}0 \\
0 \\
0 \\
15\end{array}$ & $\begin{array}{l}212 \\
213 \\
214\end{array}$ & Tem & CRBG-undiff. & $\begin{array}{l}196 \\
207 \\
213\end{array}$ & $\mid \begin{array}{c}5 \\
0 \\
0 \\
15\end{array}$ & $\begin{array}{l}\text { Columbia River } \\
\text { Basalt Group } \\
\text {-undifferentiated }\end{array}$ \\
\hline
\end{tabular}

Figure 6.5. Hanford Site lithostratigraphic color palette with associated CMYK and RGB values (figure created in Adobe Illustrator, type converted to outlines, saved as EPS file, and inserted into Word) 



\subsection{Additional Guidelines for Specific Geologic Diagrams}

For these guidelines, geological diagrams are grouped into four categories:

1. borehole and columnar sections (one-dimensional graphics)

2. geologic maps (two-dimensional horizontal or plan view graphics)

3. geologic cross sections (two-dimensional vertical or section view graphics)

4. geologic fence/block diagrams (three-dimensional graphics).

Additional guidance and recommendations for these types of geologic graphics are provided in this section.

\subsection{Borehole and Columnar Sections}

Borehole and columnar sections are defined as any one-dimensional column used to describe the vertical distribution of rock and sedimentary units, their lithology, and thickness. This category includes general stratigraphic columns of outcrops as well as borehole summary logs or measured sections. In most cases the columns will be vertical, but in some cases boreholes and wells are drilled at an angle from vertical. Borehole and columnar sections should comply with the following minimum guidelines and recommendations. Refer to the examples presented in Appendix B, Figure B.1.

- Borehole sections shall include the well name and/or well ID (or measured section ID), geographic coordinates with the coordinates fully specified (Washington State Plane South zone NAD83 meters), and an explanation of geologic symbols used (i.e., a legend).

- A scale shall appear at the left side of the column. At a minimum, depth below ground surface, in feet, shall be displayed in even increments. Either an elevation scale, in meters, or a notation of ground surface elevation, in meters, shall also be displayed. The elevation datum to be used is the North American Vertical Datum of 1988 (NAVD88).

- When displaying a graphic log of sediments, it is recommended that the right side of the column vary with average (or dominant) grain size (i.e., coarser sediment extends out farther than fine-grained sediment). This provides a visual means to illustrate subtle yet significant changes in grain size and helps to convey the nature of the contact (i.e., sharp or gradational) between strata. A suitable scale should be provided to illustrate the relative particle-size values (e.g., mud, sand, gravel).

- Other information that could be added includes total depth; date of well completion; geophysical logs; blow-count information; drill/sampling method(s); elevation at top of well or ground surface; results of laboratory analyses; or significant changes in color, consolidation, mineralogy, other features from geologist's and/or driller's comments, and/or other information dependent on the intent and audience of the graphic.

- The best estimate of formation or unit contact picks and depths should be delineated where they are known and appropriate. 


\subsection{Geologic Maps}

These guidelines consider all two-dimensional horizontal (plan view) maps used to convey the horizontal extent of geologic units, thicknesses, or any other geologic features and properties as geologic maps. This category includes, but is not limited to, surface geologic maps, structure-contour maps, isopach maps, and other maps showing the areal distributions of geologic quantities (e.g., materials, contaminants) using lines of equal or constant value. At a minimum, each geologic map should include

- coordinates and datum (e.g., state plane metric [N, E], WC83S/NAVD88)

- north arrow (true north) and an appropriate metric scale

- legend to explain any symbols used

- contour interval(s) (for topographic maps, structure-contour maps, isopach maps, contaminant plume maps, or other maps having representative contours delineated by either lines or changing colors).

\subsection{Geologic Cross Sections}

An adequate number of cross sections should be presented to depict significant geologic or structural trends and reflect geologic and structural features in relation to local and regional groundwater flow (EPA 1986). A location map or maps should be included to show the location of all cross sections presented. Each cross section should identify

- well name or ID of each borehole (or measured section) in the cross section

- names and contacts between significant geologic formations or facies

- the location of each borehole/well

- depth to the zone of saturation and date of measurement.

Other information that could be added includes lithologic variations, zones of high permeability or fracture, the screened or perforated intervals, depth of termination, geophysical logs, contours of permeability or contaminant concentration, and/or other information dependent on the intent and audience of the graphic.

In addition, each cross section or group of cross sections should include the amount of vertical exaggeration, vertical scales and datum, and a legend. The use of vertical exaggeration should be minimized to where needed to show subtle structural differences (e.g., when there is a large crosssectional horizontal distance and a relatively small vertical distance). Significant structural features also should be included.

Where multiple cross sections intersect, the information at intersecting wells shall be the same on each cross section.

\subsection{Geologic Fence/Block Diagrams}

Fence/block diagrams generally have the same requirements as cross sections. 


\subsection{Examples of Software for Generating Geologic Graphics}

The following native software applications are recommended for creating geologic graphics, as long as recent versions of the application are used and the file is labeled with the correct extension. Note that files created in graphics applications are usually required to be converted to a general vector or raster file format if the graphic is to be used outside the native graphics program.

- Adobe Illustrator (file extension .ai) - This is one of the best applications for creating geologic graphics. However, this refers to graphics actually created in Illustrator, not figures that were created in another program and then imported into Illustrator. Native .ai files are not compatible with most text processing or document processing software and usually need to be converted to a general vector or raster file format if the graphic is to be used outside Illustrator.

- ACD Systems of America, Inc. Canvas (file extension .cvx) - Native .cvx files are not compatible with most text processing or document processing software and usually need to be converted to a general vector or raster file format if the graphic is to be used outside Canvas.

- CorelDRAW (file extension .cdr) - Native .cdr files are not compatible with most text processing or document processing software and usually need to be converted to a general vector or raster file format if the graphic is to be used outside CorelDRAW.

- Adobe Photoshop (file extension .psd) - Native .psd files are not compatible with most text processing or document processing software and usually need to be converted to a general vector or raster file format if the graphic is to be used outside Photoshop.

- Other graphic files created with specialized software, such as Hydro GeoAnalyst, Rockworks, LogPlot, EarthVision, ArcView, and AutoCAD, need to be converted to PNG, JPEG, TIFF, EPS, or PDF format for use outside their native software. Their native file formats are generally not compatible with software typically used for general graphics creation, text processing, or document processing.

- Adobe FreeHand (file extension .fh) - It is best to supply native FreeHand files. This is legacy software. No updates to FreeHand have been made for several years, and Adobe has no plans to initiate development to add new features or to support current computing platforms or operating systems. Adobe recommends upgrading from FreeHand to Illustrator.

Legacy files of geologic graphics that were generated with previous (i.e., not current) versions of these software applications may be opened and modified using current versions of the applications. However, the file may have to be extensively edited, or even a new graphic generated from scratch, because of modifications to the computer code in successive versions of the software.

Note: If a geologic graphic is placed or inserted into a document created with a text processer (e.g., Microsoft Word), a presentation processor (e.g., Microsoft PowerPoint), or a document processer (e.g., Adobe InDesign), the graphic will be subject to those programs' internal graphics-handling capabilities and may not look or print as when viewed in or printed from the native graphics program. 



\subsection{Geologic Graphics Database and Documentation}

Upon publication of geologic images in DOE-RL or Hanford subcontractor reports, copies of the associated geologic graphics files should be placed into a repository of geologic images located in a geologic graphics database accessible to all Hanford Site contractors. Images on this intranet server, accessible to other producers of DOE and subcontractor reports, can then be used by other investigators in subsequent reports.

At present, there is no production-level Hanford Site geologic graphics database. However, a geologic graphics catalog/database is under development.

Up to three copies of each image should be created for placement onto the repository server-one would be in the original format native to the software in which it was created, and the others in converted vector and/or raster files as specified in Table 6.1. A metadata file (filename.met) should accompany each graphic. This file should identify the author of the graphic, sources of key data (e.g., boreholes, waste sites), and any appropriate acknowledgments or references.

Note: All subsequent use and reproduction of these graphics files shall be accompanied by the appropriate acknowledgement and/or references to the origin. 



\subsection{References}

ASTM Standard D4750, 1987. 2001. "Standard Test Method for Determining Subsurface Liquid Levels in a Borehole or Monitoring Well (Observation Well).” ASTM International, West Conshohocken, Pennsylvania.

Delany CD, KA Lindsey, and SP Reidel. 1991. Geology and Hydrology of the Hanford Site: A Standardized Text for use in Westinghouse Hanford Company Documents and Reports. WHC-SD-ERTI-003, Westinghouse Hanford Company, Richland, Washington.

DOE-RL. 2002. Standardized Stratigraphic Nomenclature for Post-Ringold-Formation Sediments Within the Central Pasco Basin. DOE/RL-2002-39, U.S. Department of Energy Richland Operations Office, Richland, Washington.

DOE-RL. 2007. Hanford Integrated Groundwater and Vadose Zone Management Plan. DOE/RL-200720, U.S. Department of Energy Richland Operations Office, Richland, Washington.

FGDC (Federal Geographic Data Committee). 2006. FGDC Digital Cartographic Standard for Geologic Map Symbolization. Federal Geographic Data Committee Document Number FGDC-STD-0132006, U.S. Geological Survey, Reston, Virginia.

Hansen WR (ed). 1991. Suggestions to Authors of the Reports of the United States Geological Survey, Seventh Edition. U.S. Geological Survey, U.S. Government Printing Office, Washington, D.C.

Last GV and TL Liikala. 1987. A Field Guide for Well Site Geologists: Cable Tool Drilling. PNL6392, Pacific Northwest Laboratory, Richland, Washington.

Lindsey KA. 1995. Miocene- to Pliocene-Aged Suprabasalt Sediments of the Hanford Site, SouthCentral Washington. BHI-00184, Bechtel Hanford, Inc., Richland, Washington.

Lindsey KA. 1996. The Miocene to Pliocene Ringold Formation and Associated Deposits of the Ancestral Columbia River System, South-central Washington and North-central Oregon. Open File Report 96-8, Washington Division of Geology and Earth Resources, Washington State Department of Natural Resources, Olympia, Washington.

NACSN (North American Commission on Stratigraphic Nomenclature). 2005. "North American Stratigraphic Code." AAPG Bulletin 89(11):1547-1591.

Reidel SP, KA Lindsey, and KR Fecht. 1992. Field Trip Guide to the Hanford Site. WHC-MR-0391, Westinghouse Hanford Company, Richland, Washington.

Swanson DA, TL Wright, PR Hooper, and RD Bentley. 1979. Revisions in Stratigraphic Nomenclature of the Columbia River Basalt Group. Geological Survey Bulletin 1457-G, U.S. Government Printing Office, Washington, D.C. 
Thorne PD, MP Bergeron, MD Williams, and VL Freedman. 2006. Groundwater Data Package for Hanford Assessments. PNNL-14753 Rev. 1, Pacific Northwest National Laboratory, Richland, Washington.

USGS. 1999. "USGS Geologic Division Publications Requirements for Digital Map Products.” U.S. Geological Survey, Reston, Virginia. Available at http://ncgmp.usgs.gov/ngmdbproject/standards/ dataexch/USGSpolicy.html (April 2010).

USGS. 2005. Selection of Colors and Patterns for Geologic Maps of the U.S. Geological Survey. Techniques and Methods 11-B1, U.S. Geological Survey, Reston, Virginia. Available at http://pubs.usgs.gov/tm/2005/11B01/ (April 2010).

USGS. 2006. "National Cooperative Geologic Mapping Program - Geologic Mapping Standards." U.S. Geological Survey, Reston, Virginia. Available at http://ncgmp.usgs.gov/ncgmpstandards/ (April 2010).

Williams BA, BN Bjornstad, R Schalla, and WD Webber. 2001. Revised Hydrogeology for the Suprabasalt Aquifer System 200-East Area and Vicinity, Hanford Site, Washington. PNNL-12261, Pacific Northwest National Laboratory, Richland, Washington.

Williams BA, BN Bjornstad, R Schalla, and WD Webber. 2002. Revised Hydrogeology for the Suprabasalt Aquifer System, 200-West Area and Vicinity, Hanford Site, Washington. PNNL-13858, Pacific Northwest National Laboratory, Richland, Washington.

Wurstner SK, PT Thorne, MA Chamness, MD Freshley, and MD Williams. 1995. Development of a Three-dimensional Ground-Water Model of the Hanford Site Unconfined Aquifer System: FY 1995 Status Report. PNL-10886, Pacific Northwest Laboratory, Richland, Washington. 


\subsection{Bibliography}

Bates RL and JA Jackson (eds). 1987. Glossary of Geology. 3rd edition. American Geological Institute, Alexandria, Virginia.

DOE. 1988. Consultation Draft, Site Characterization Plan, Reference Repository Location, Hanford Site, Washington. DOE/RW-0164, Volumes 1-9. U.S. Department of Energy, Office of Civilian Radioactive Waste Management, Washington, D.C.

Elsevier. 2010. “Author Artwork Instructions.” Available at

http://www.elsevier.com/framework_authors/Artwork/Artwork_2010.pdf (April 2010).

Geological Society of America. 2010. "GSA Bulletin - Section 5, Tables and Figures.” Available at http://www.geosociety.org/pubs/bulletin/bulGuide4.htm (April 2010).

Council of Biology Editors, Inc. 1994. Scientific Style and Format - The CBE Manual for Authors, Editors, and Publishers. 6th edition. Cambridge University Press, New York.

EPA. 1986. Resource Conservation and Recovery Act (RCRA) Ground-Water Monitoring Technical Enforcement Guidance Document. PB87-107751 (OSWER-9950.1), Office of Waste Programs Enforcement, U.S. Environmental Protection Agency, Washington, D.C.

EPA. 1987. Handbook, Groundwater. EPA/625/6-87/016, U.S. Environmental Protection Agency, Office of Research and Development, Center of Environmental Research Information, Cincinnati, Ohio, and Robert S. Kerr Environmental Research Laboratory, Ada, Oklahoma

Wiley-Blackwell. 2010. "Electronic Artwork - An Introduction.” Available at http://authorservices.wiley.com/electronicartworkguidelines.pdf(April 2010). 

Appendix A

Lithologic and Well Completion Symbols Used at the Hanford Site 



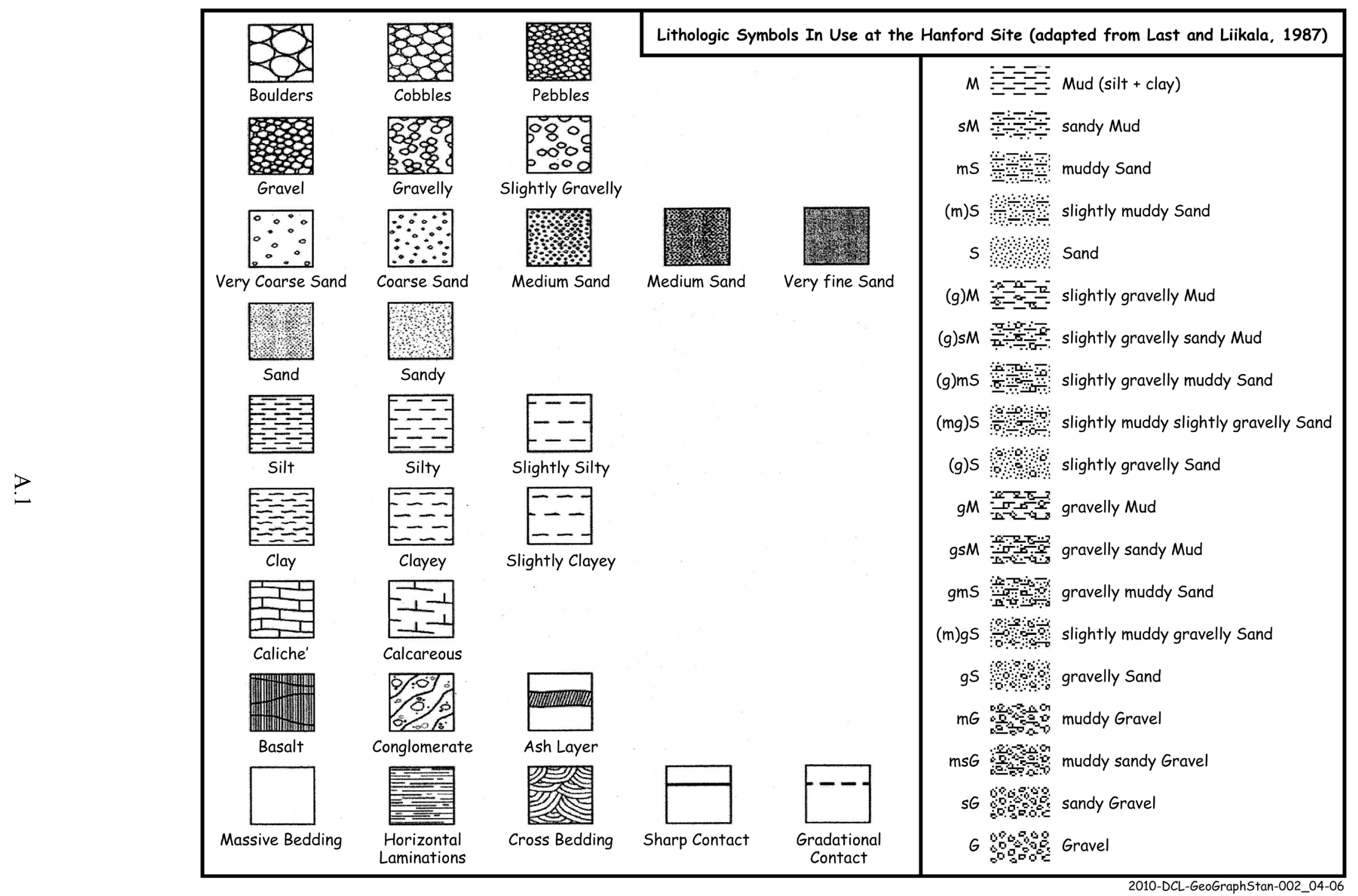

Figure A.1. Lithologic symbols in use at the Hanford Site 
Well Completion Symbols In Use at the Hanford Site (adapted from Last and Liikala, 1987)

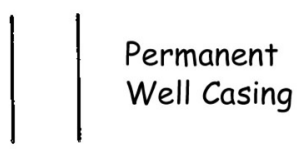

1 Casing Joint

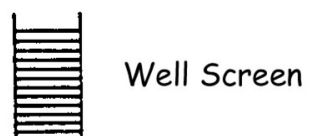

$\nabla$ Water Level

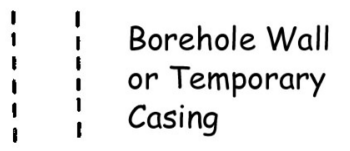

青 Perforated

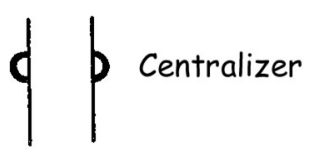

Well Completion Materials

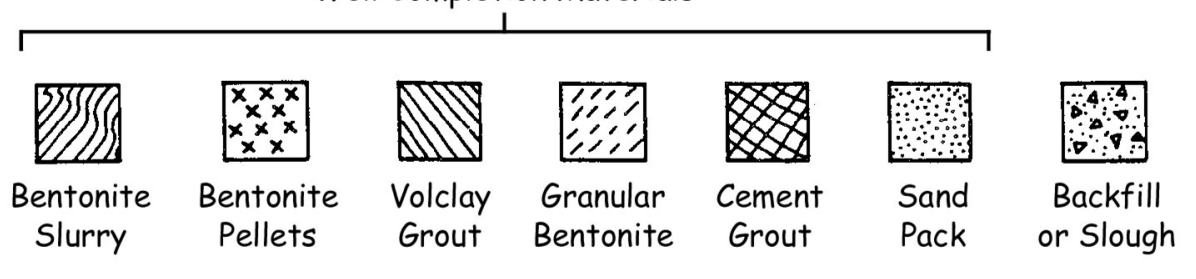

2010-DCL-GeoGraphStan-003_04-06

Figure A.2. Well completion symbols in use at the Hanford Site 
Appendix B

Geologic Graphics Examples 



\section{Appendix B}

\section{Geologic Graphics Examples}

The figures in this appendix exemplify the guidelines for the graphical presentation of geologic information:

- B.1. Borehole section summary log: a) original size; b) reduced size

- B.2. Cross section and location map

- B.3. Fence diagram

- B.4. Isopach map

- B.5. Structure-contour map

- B.6 Borehole section log plot: a) reduced size; b) original size. 


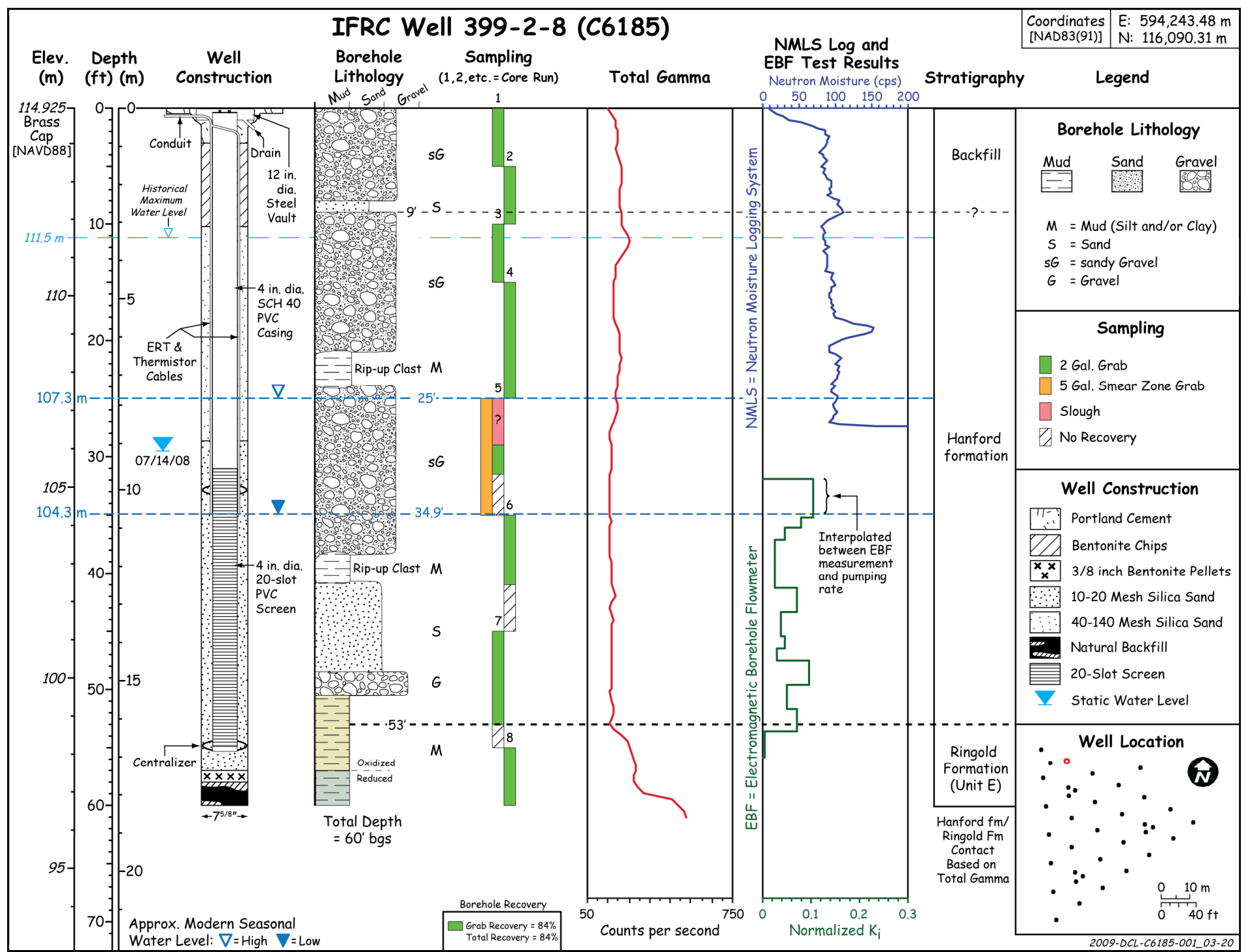

Figure B.1(a). Borehole section summary log at near original size (Comic Sans MS font, created in Illustrator, saved as 300-dpi PNG file, inserted into Word file) 


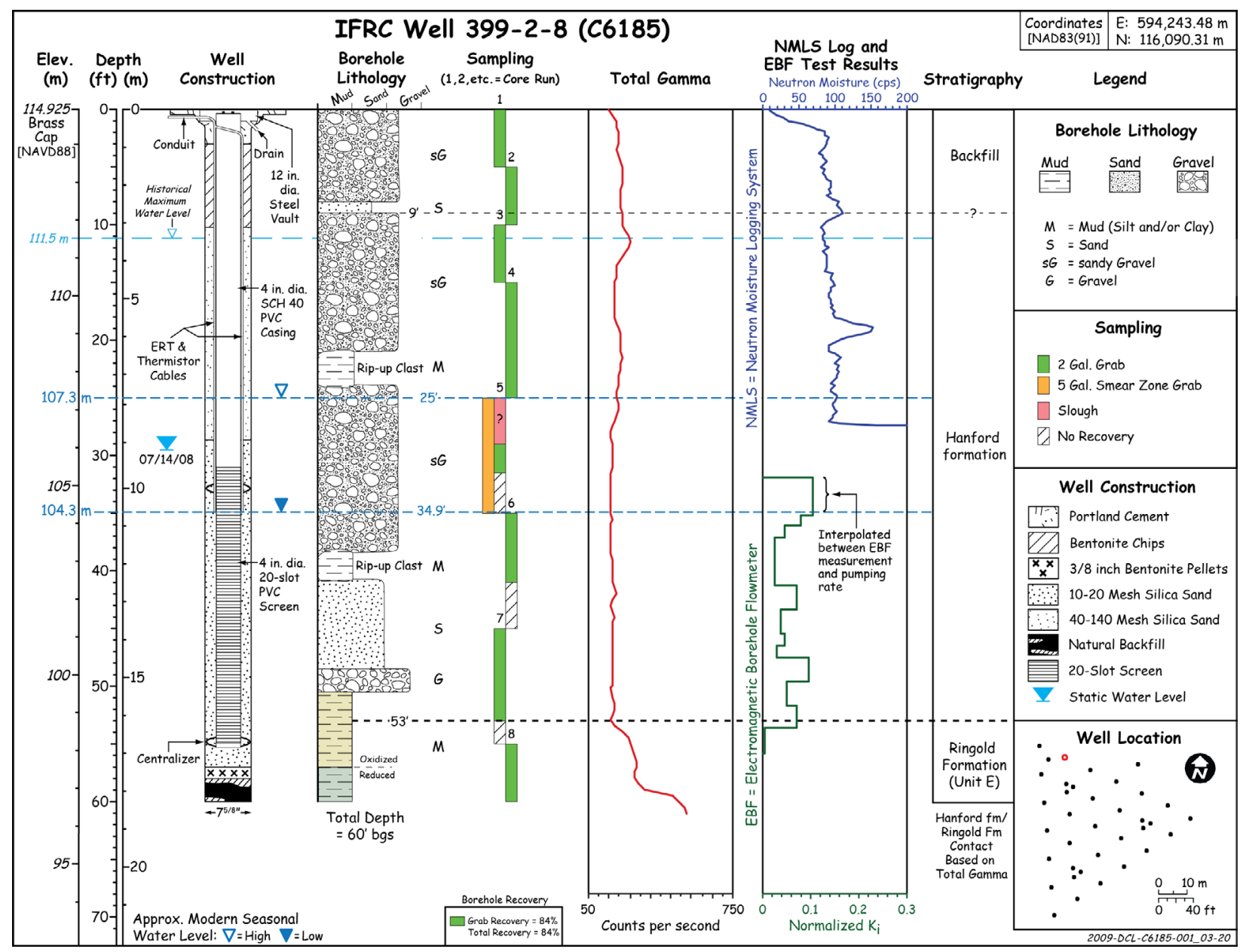

Figure B.1(b). Borehole section summary log at reduced size (Comic Sans MS font, created in Illustrator, saved as 300-dpi PNG file, inserted into Word, and scaled down to 6.5-inch width) 


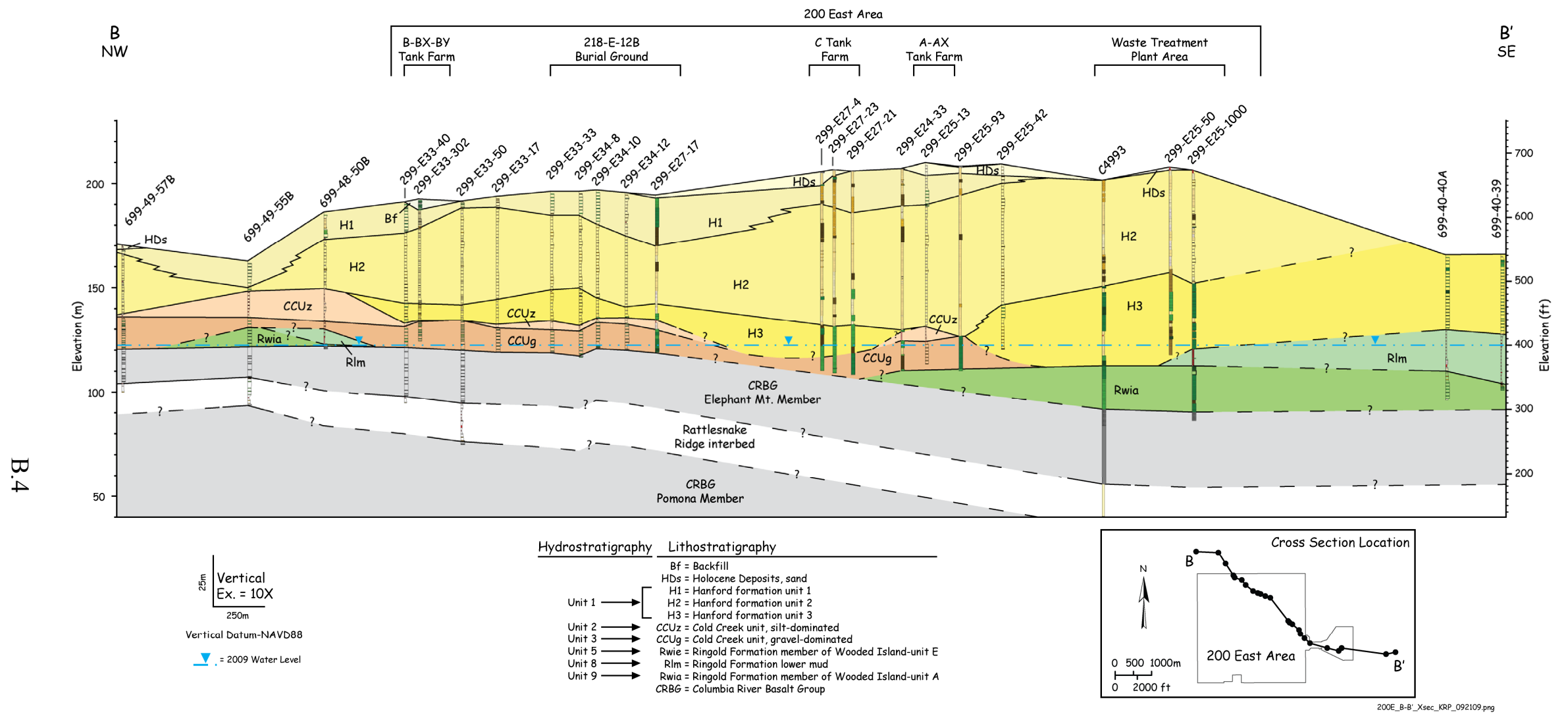

Figure B.2. Cross section and location map (Comic Sans MS font, created in Illustrator, saved as 300-dpi PNG file, inserted into Word, and scaled down from 11- $\times 17$-inch original size) 

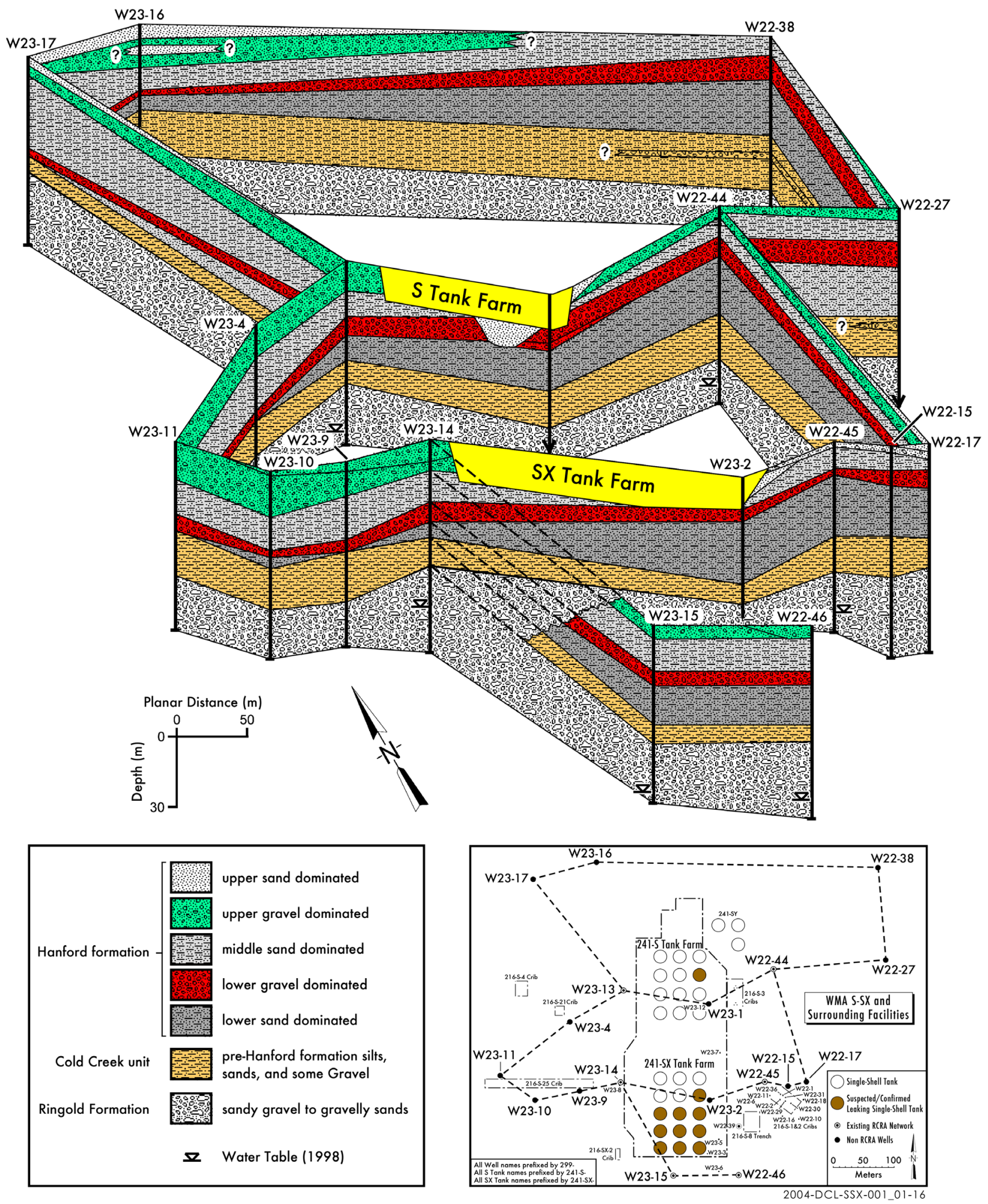

Figure B.3. Fence diagram (Futura font, created in Canvas, saved as 300-dpi PNG file, inserted into Word, and scaled down in size) 


\section{H3 ISOPACH MAP}

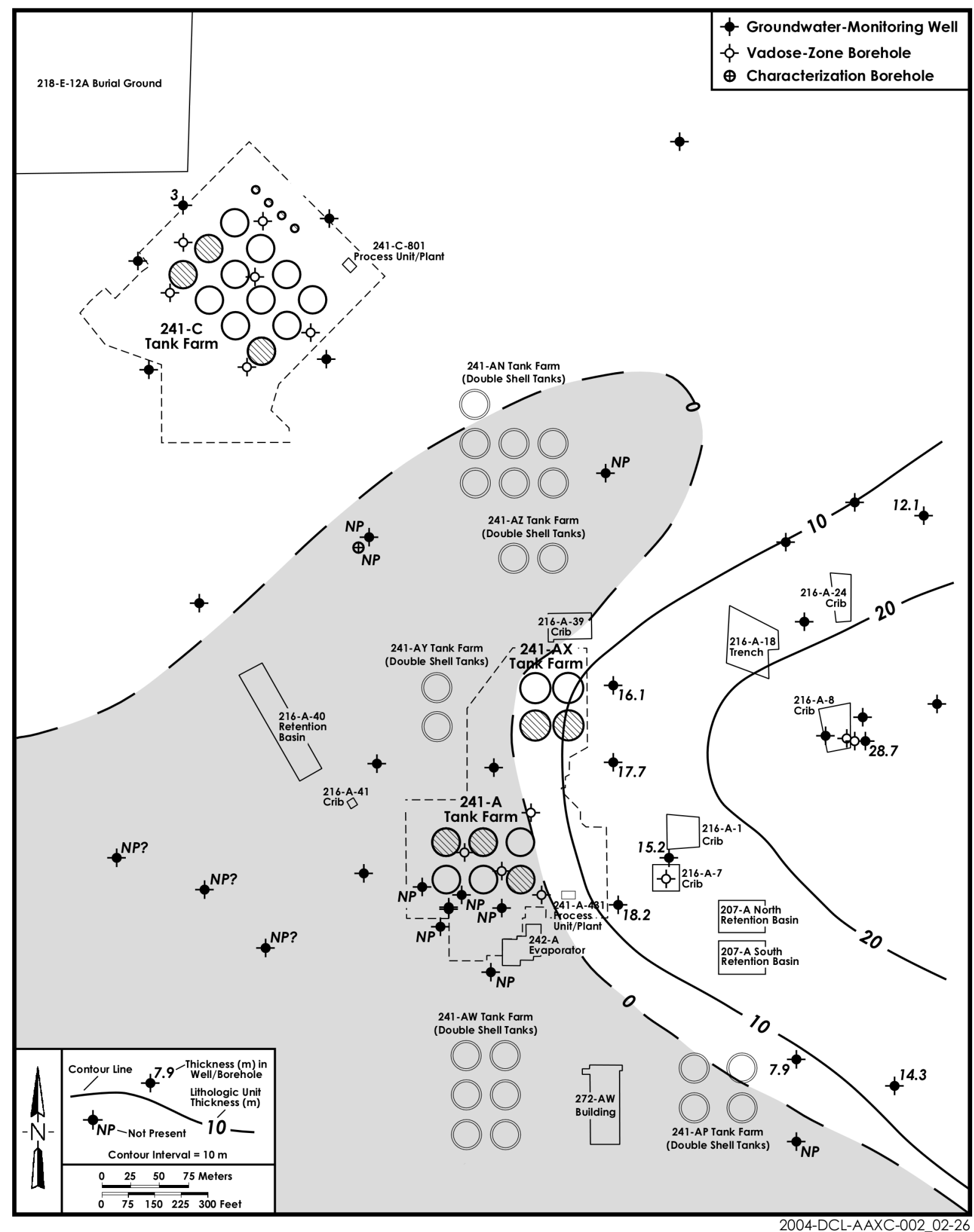

Figure B.4. Isopach map (Century Gothic font, created in Canvas, saved as 300-dpi PNG file, inserted into Word, and scaled down in size) 


\section{TOP OF $\mathrm{CCU}_{\mathrm{U}}$ MAP}

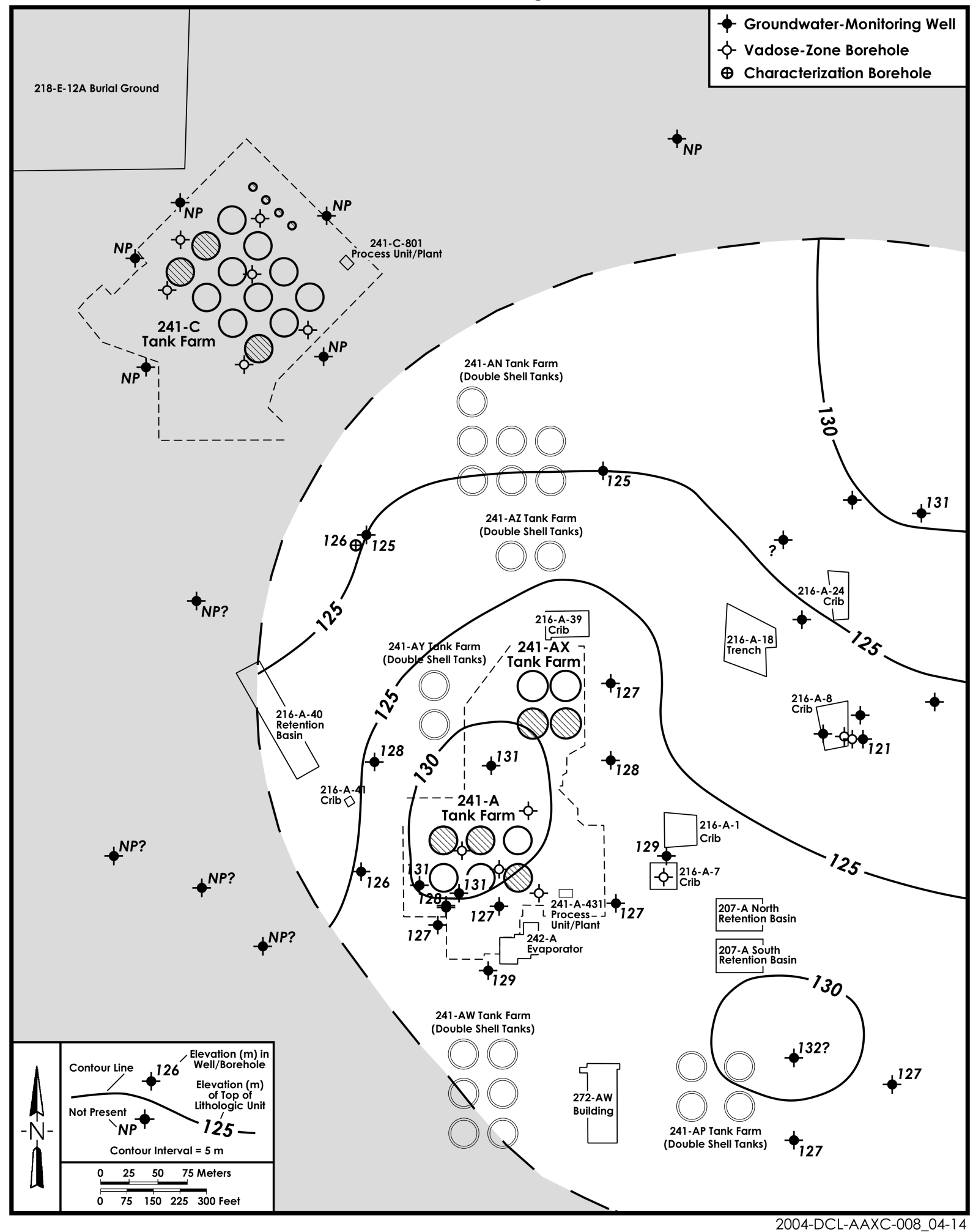

Figure B.5. Structure-contour map (Century Gothic font, created in Canvas, saved as 600-dpi PNG file, inserted into Word, and scaled down in size) 


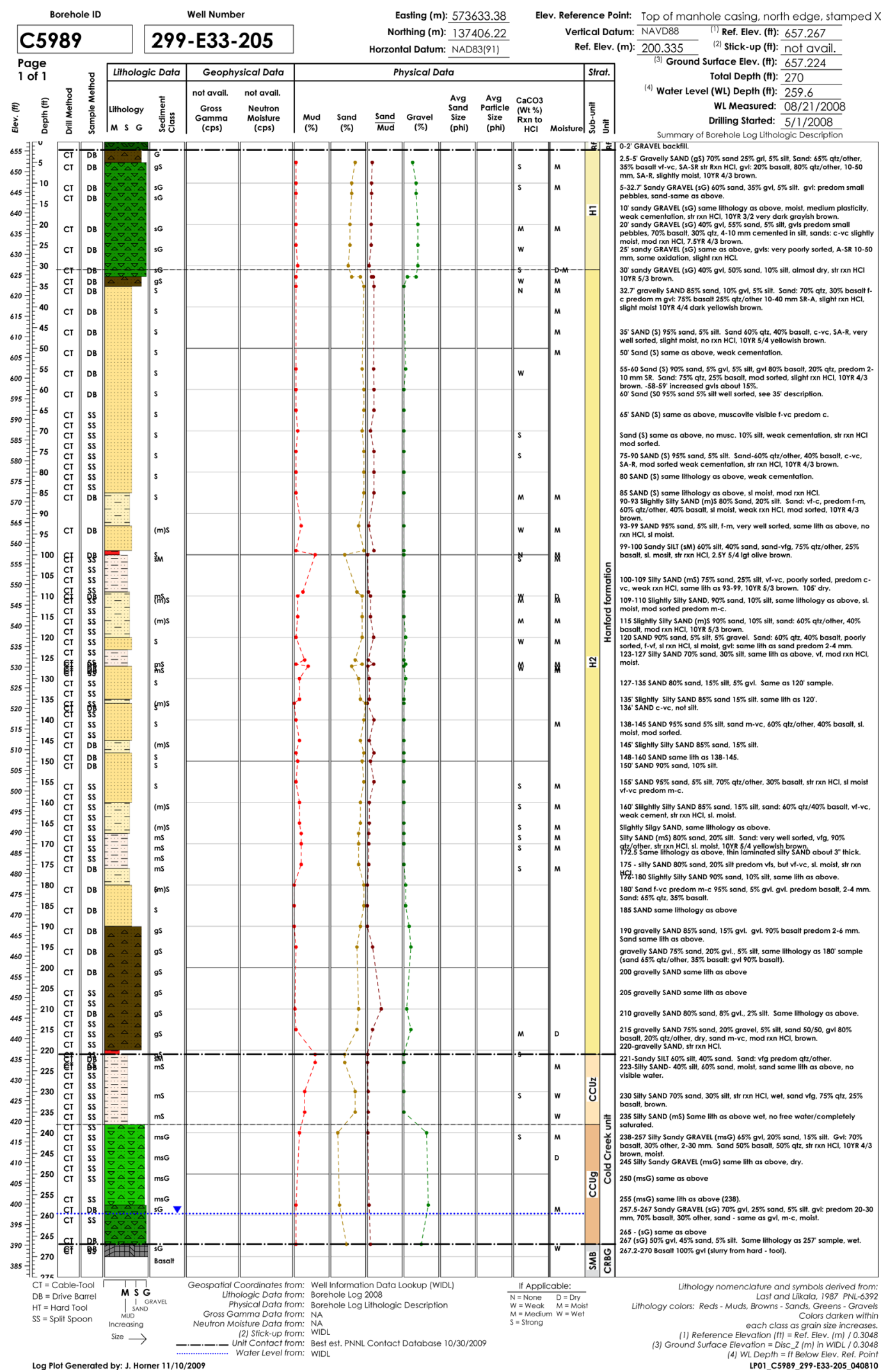

Figure B.6(a). Borehole section log plot (600-dpi PNG), scaled down from 11- $\times$ 17-inch original size 


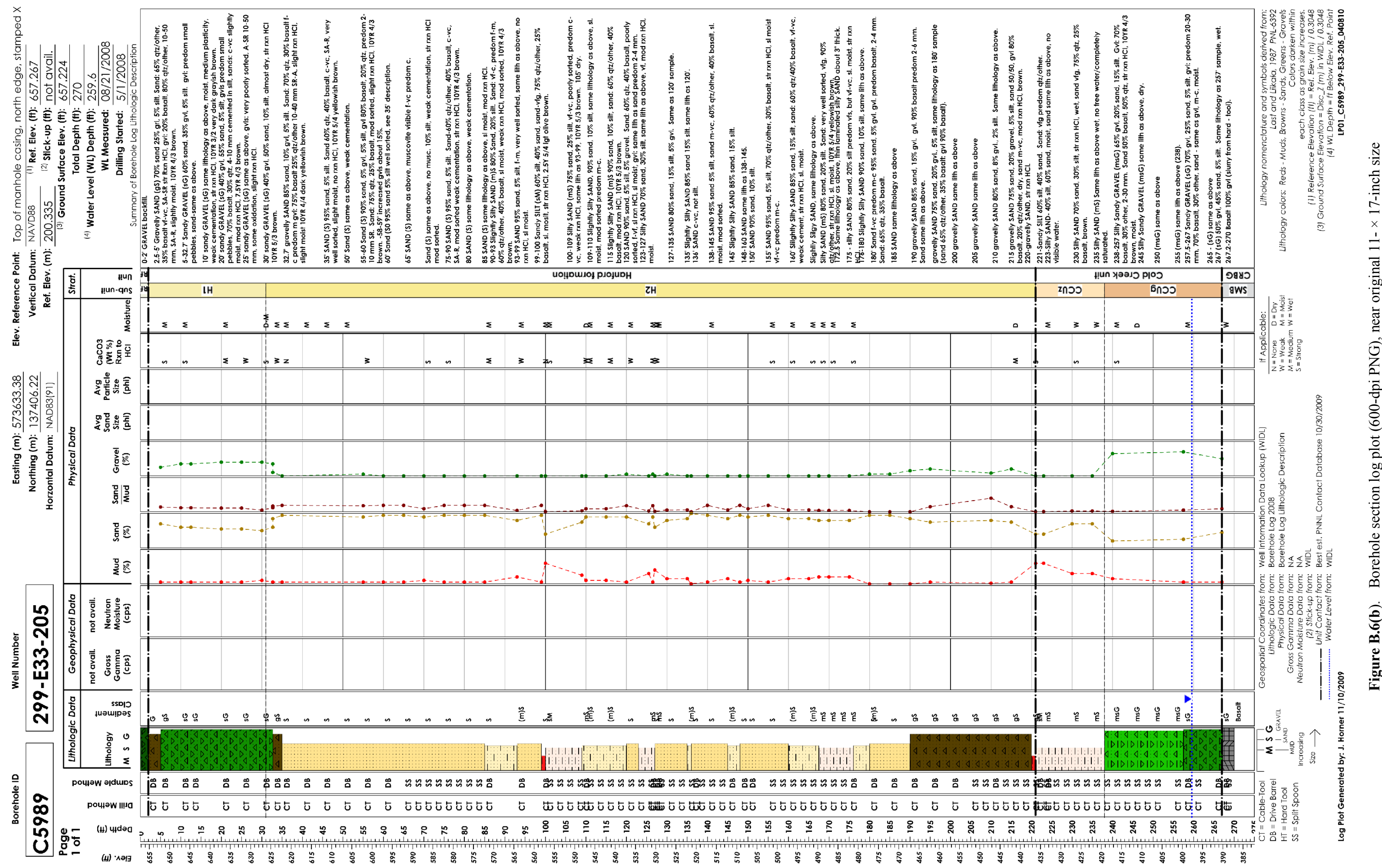





\section{Distribution}

No. of

Copies

\section{OFFSITE}

S. P. Airhart

Freestone Environmental Services, Inc.

1100 Jadwin Avenue, Suite 250

Richland, WA 99352

P. Cabbage

Freestone Environmental Services, Inc.

1100 Jadwin Avenue, Suite 250

Richland, WA 99352

J. Ludwig

INTERA, Inc.

1933 Jadwin Avenue, Suite 130

Richland, WA 99354

\section{ONSITE}

8 CH2M HILL Plateau Remediation

Company
R. E. Day
H8-15
B. H. Ford
$\mathrm{H} 8-43$
D. E. McKenney
H8-43
V. J. Rohay
H8-15
W. D. Webber
H8-15
B. A. Williams (3)
H8-51

1 Fluor Federal Services

$\begin{array}{ll}\text { R. Khaleel R3-50 } & \text { R }\end{array}$

15 Pacific Northwest National Laboratory

B. N. Bjornstad

K6-81

J. D. Horner

K6-96

D. C Lanigan (3)

K6-75

G. V. Last (3)

K6-81

R. D. Mackley

K6-96

C. J. Murray

K6-81

B. E. Opitz

K6-75

K. R. Parker

K6-96

R. G. Riley

K6-81

P. D. Thorne

K6-96

Information Release Office

P8-55 




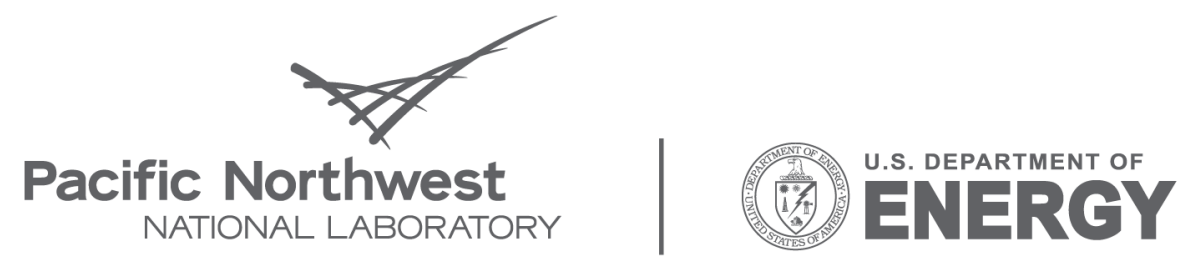

Proudly Operated by Battelle Since 1965

902 Battelle Boulevard

P.O. Box 999

Richland, WA 99352

1-888-375-PNNL (7665)

www.pnl.gov 